
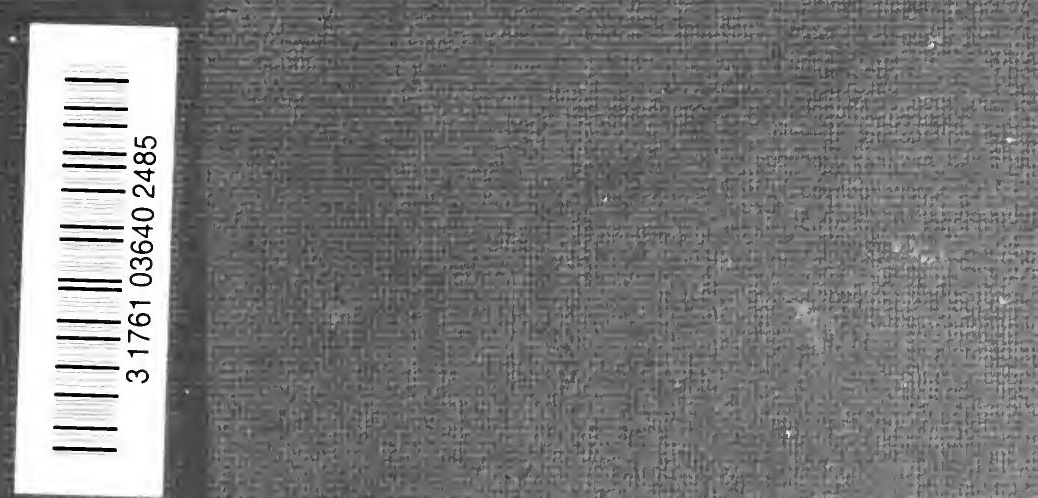





\section{THE INFLUENCE OF BEN JONSON ON ENGLISH COMEDY}





\title{
INFLUENCE OF BEN JONSON ON ENGLISH COMEDY 1598-1642
}

\author{
BY \\ MINA KERR \\ Dean of Milwaukee-Downer College
}

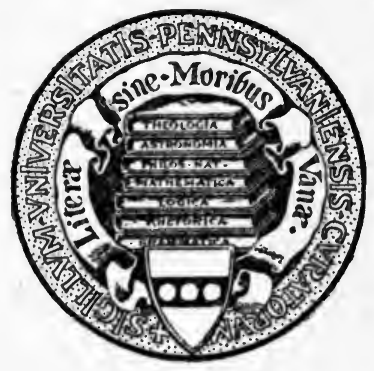

UNIVFRSITY OF PENNSYLVANIA

D. APPLETON AND COMPANY, AGENTS, NEW YORK

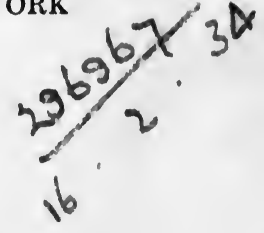


Copyright, 1912

By the University of Pennsyluania

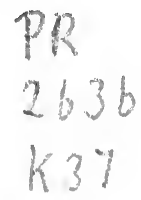

J. F. TAPLEY CO.

NEW YORK 


\section{PREFACE}

This study of Ben Jonson's influence on Elizabethan and Restoration comedy has been made at the suggestion of Professor Felix E. Schelling, and has been done in partial fulfillment of the requirements for the degree of Doctor of Philosophy at the University of Pennsylvania. Much suggestion and direction have been gained from Ward's History of English Dramatic Literature, Schelling's Elizabethan Drama, and Woodbridge's Studies in Jonson's Com$e d y$. The method pursued has consisted for the most part of a first-hand examination and comparison of the plays written by Jonson, his contemporaries and later followers. The question of how far and in what way one man's work has been influenced by that of another is always open to dispute, and it is impossible to fix absolute limits. The ever-present danger is that of finding what one is looking rather than what actually exists. Many quotations have been included, especially from minor writers, so as to put before the reader as far as possible the materials upon which judgment has been based.

I desire to express my gratitude to Professor Felix E. Schelling of the University of Pennsylvania for his wise counsel and gracious encouragement during the preparation of this monograph, and for the many valuable suggestions he has given out of his broad and minute knowledge of the history and content of Elizabethan drama.

M. K.

Milwaukee-Downer College,

December, 1911. 



\section{CONTENTS}

Chapter

PAGE

I. The Character of Jonson's Comedy . . . . . . . 1

II. The Influence of Jonson's Comedy on that of His Immediate Contemporaries . . . . . . . . . 18

III. Nathaniel Field and Richard Brome in Relation to Jonson . . . . . . . . . . . . . . 52

IV. Other "Sons of Ben" in English Comedy before the Closing of the Theaters in 1642 . . . . . . . 76

V. Conclusion . . . . . . . . . . . . . 120

Bibliography . . . . . . . . . . . . . 125

Index . . . . . . . . . . . . . . . 128 
"But all so clear, and led by Reason's flame, As but to stumble in her sight were shame; These I will honor, love, embrace, and serve, And free it from all question to preserve. So short you read my character, and theirs I would call mine, to which not many stairs Are asked to climb. First give me faith, who know Myself a little; I will take you so, As you have writ yourself: now stand, and then, Sir, you are Sealed of the Tribe of Ben." An Epistle, Answering to One that Asked to be sealed of the Tribe of Ben.

"Son, and my friend, I had not called you so To me; or been the same to you, if show, Profit, or chance had made us: but I know, What, by that name, we each to other owe, Freedom and truth; with love from those begot: Wise-crafts, on which the flatterer ventures not." An Epigram to a Friend and Son. 


\section{The Influence of Ben Jonson on English Comedy}

\section{CHAPTER I}

THE CHARACTER OF JONSON'S COMEDY

The purpose in the present study is to follow but one of the lines along which the work of Ben Jonson affected English literature, to determine where, how, and to what extent, his influence was felt in comedy as written by contemporaries and later "Sons" between 1598, when Every Man in His Humor was first acted, and the closing of the theaters in 1642. It is helpful, first of all, to consider what in Jonson gave him the power of attaining the position of importance which he holds in English dramatic history, and necessary to define clearly what were the distinguishing characteristics of his comedy, in order to set up criteria by which to judge the presence or absence of his influence.

The nature of Jonson's personality and the character of his art were both such as would inevitably draw to him many loyal followers. His first essay in the comedy of humors marked him out at once as a writer of originality and power among his contemporary craftsmen. Some of these opposed what was plainly the blazing of a new path in English comedy, but others applauded enthusiastically, and soon showed in their own work evidences of approval and acceptance of the new method. In his later years Jonson was surrounded by a group of young disciples, who 
were proud to be "Sealed of the Tribe of Ben," and who looked upon the patriarch of their clan both as chief of good comrades and as supreme authority in matters of literature. Whether in comedy, tragedy, masque, epigram, or occasional verse, in matter or form, he was regarded as a dictator, so that both during his own age and during the following century we find unmistakable and effective traces of his influence.

There are several reasons why Ben Jonson had such position and power in establishing a new school. First of all, his art and workmanship were thoroughly self-conscious, and he had fixed, positive theories about literature. These he talked continuously and vociferously for forty years and explained clearly in his inductions, prefaces, prologues, epilogues, and Discoveries, so that there could be no doubt as to what he believed on each and every question of literary art. With his first play he set forth definite dramatic methods, and for the most part he made his practice to accord with his theories. Further, whatever idea or theory he adopted received his vigorous, wholehearted support; and hence his statements of literary creed were positive assertions, free from the numerous modifications and exceptions that may be necessary for completeness and the most exact truth, but which, nevertheless, tend to involve in uncertainty those who would imitate. Jonson's theory and art were, therefore, such as could be readily laid hold of and patterned after. Again, in literary as in other fashions originality and novelty act as powerful forces in gaining followers, and Jonson in his first comedy of humors made a deliberate innovation, undertaking what had never before been done in English drama. In the prologue to Every Man in His Humor he foretold a reaction from romantic and idealistic to classic and realistic drama, and declared that he would portray 
"deeds and language such as men do use, And persons such as comedy would choose, When she would show an image of the times, And sport with human follies, not with crimes."

Certainly the personality of this remarkable man had much to do with the desire of those who knew and loved him to follow along the same paths in literature. He won loyal friends and as strong enemies in his personal life, enthusiastic followers in his particular form of art and as decided opponents. That he had a warm heart and a rare eapacity for friendship or that his relations to people were marked by unusual intensity and sincerity, no one can doubt who has read his various dedications, poems, and the Discoveries. His very weaknesses were the weaknesses of strength, and he was a most human mixture of qualities,forceful but intolerant, warm in praise but self-assertive, clear in thought and speech but arrogant, just in judgment but imprudent, never passive or affected but always passionate and sincere-a man toward whom others could not remain indifferent, but whom they must either love or hate warmly.

At the various taverns of London, Jonson reigned among his fellows and later his disciples by right of character, wit and learning. Of the early days at the Mermaid, Beaumont wrote in a letter to Jonson:

\section{"what things have we seen,}

Done at the Mermaid! heard words that

Have been so nimble, and so full of subtle flame, As if that every one from whom they came, Had meant to put his whole wit in a jest."

The merry feasts of wit and laughter that took place later in the famous Apollo Room of the Devil Tavern at Tem- 
ple Bar and in other public houses of the day, Herrick celebrates in his well-known verse:

"Ah Ben!

Say how or when

Shall we thy guests

Meet at those lyric feasts

Made at the Sun,

The Dog, the Triple Tun?

Where we such clusters had,

As made us nobly wild, not mad;

And yet each verse of thine

Outdid the meat, outdid the frolic wine."

The real character of these meetings we may judge best, however, from the Leges Convivales written by Ben Jonson himself and engraved in marble over the chimney in the Apollo Room. There are described the guests invited to join the happy company:

"Let the learned and witty, the jovial and gay, The generous and honest, compose our free state."

There we learn that, while the ordinary theater of the day was no fit place for women, the conduct of the Apollo Club was such that they could be freely admitted to its meetings :

\section{"And the more to exalt our delight whilst we stay,} Let none be debarred from his choice female mate."

Among the other rules laid down were these:

"Let the contests be rather of books than of wine. Let the company be neither noisy nor mute. 
Let none of things serious, much less of divine, When belly and head's full, profanely dispute." "Let raillery be without malice or heat." "Let argument bear no unmusical sound, Nor jars interpose, sacred friendship to grieve." 1

The Leges Convivales testify that the Apollo Club aimed to hold sacred things sacred, honor women, exclude malicious speech, respect learning, prize friendship, and they convince us that the meetings were characterized by true nobility of tone. It was surely through these happy gatherings that many comrades and "Sons of Ben," learning to understand and admire the character and art of Jonson, were moved to accept him as master in their own literary attempts.

Lowell, in his essay on Shakespeare Once More, asserts that "no poet of the first class has ever left a school, because his imagination is incommunicable;" that "you may detect the presence of a genius of the second class in any generation by the influence of his mannerism, for that, being an artificial thing, is capable of reproduction." ${ }_{2}$ It is true that the highest poetic gift of imagination or what Lowell calls "aeration of the understanding by the imagination" can not be imitated. We must not look in Jonson's dramatic work, nor in that of his followers as influenced by him, for essential charm, for deep tenderness, for sublime tragedy and pathos, for the inevitability of the very greatest poetry. Many truly great qualities we may find. Jonson's place is not, as Swinburne puts it, among the gods of harmony and creation in English literature, but among the giants of energy and invention, where he stands supreme.

The ethical aim Jonson placed foremost in his theory of

1 Jonson, Works, ed. by Gifford, 3 vols., III, 364, 365.

2 Lowell, Works, Riverside ed., III, 38. 
comedy. He was frankly, consciously didactic, and his whole dramatic career was a battle against vice and folly. From beginning to end, he assumed the attitude of a censor and reformer, purposing always through the laughter of comedy to improve morals and correct taste. It is possible to quote many passages from the plays where the moral intent is plainly stated. Asper in Every Man out of His Humor, representing Jonson himself, declares:

"with an armed and resolved hand, I'll strip the ragged follies of the time Naked as at their birth.

I fear no mood stamped in a private brow, When I am pleased t' unmask a public vice.", 3 "Well I will scourge those apes, And to these courteous eyes oppose a mirror, As large as is the stage whereon we act; Where they shall see the time's deformity Anatomized in every nerve and sinew With constant courage, and contempt of fear."

The prologue to Volpone defends the poet

"Whose true scope, if you would know it, In all his poems still hath been this measure, To mix profit with your pleasure." ${ }_{5}$

Again, the prologue to The Alchemist asserts that

"this pen

Did never aim to grieve, but better men; Howe'er the age he lives in doth endure The vices that she breeds, above their cure.

3 Jonson, Works, I, 65; Induction.

4 Ibid., I, 67.

s Ibid., I, 336. 
But when the wholesome remedies are sweet, And in their working gain and profit meet, He hopes to find no spirit so much diseased, But will with such fair correctives be pleased." .

Even in the masques Jonson does not forget "that rule of the best artist, to suffer no object of delight to pass without his mixture of profit and example." 7 His method of teaching was by dramatic satire. Like Swift, Carlyle, and all great satirists, Jonson was an ardent idealist, whose spirit was so deeply stirred by the contrast between his ideals and the actualities around him that in passionate bitterness he sought to scourge men out of their follies and vices, and to spur them by negative teaching to knowledge and virtue.

Jonson was a classicist, and his comedies were written under the guidance of "tart Aristophanes, neat Terence, witty Plautus." He was thoroughly familiar with Greek and Latin literature, and whether the need were in plot, character, description, or philosophical maxim, there was no lack of material from classical sources stored up in the poet's mind ready to be poured forth. His was what Dr. Schelling calls an "assimilative classicism." What he read he made so completely his own that his illustrations and quotations from the classics form an organic part of his writings. Symonds says of him: "He held the prose writers and poets of antiquity in solution in his spacious memory. He did not need to dovetail or weld his borrowings into one another; but rather, having fused them in his own mind, poured them plastically forth into the mold of thought." 8 However, as Jonson himself asserts both in the prologue to Every Man out of His

- Jonson, Works, II, 4.

7 Ibid., III, 45.

8 Symonds, Ben Jonson, 52. 
Humor and in the Discoveries, he was no slavish follower of the ancients, but always so broadened classical theories as to make them applicable to English conditions. The artistic logic and careful construction as well as the finish and restraint of his comedies were due in large measure to his understanding knowledge of the spirit and form of classic comedy.

He was a scholar-poet and his learning embraced not only Latin and Greek knowledge but also Renaissance lore and literature, and even extended to the arts and sciences of his own day. Whether the subject were alchemy, cookery, botany, or cosmetics he wrote with equal fullness and ease. Furthermore, he was the only playwright of the times who sought to avoid anachronisms and had conscientious regard for historical accuracy. Symonds closes his study of Jonson with this tribute: "What we most marvel at in his writings, is the prodigious brain-work of the man, the stuff of constant and inexhaustible cerebration they contain. Moreover, we shall not be far wrong in saying that, of all the English poets of the past, he alone, with Milton and Gray, deserves the name of a great and widely learned scholar.',

With this weight of learning, Jonson naturally does not rule in the kingdom of the heart but in the realm of the intellect. The appeal in all his dramas is directly and fundamentally intellectual. He cares to win commendation only from "the judicious." In the prologue to Cynthia's Revels, he describes the audience sought by his muse:

"Pied ignorance she neither loves nor fears.

Nor hunts she after popular applause,

Or foamy praise, that drops from common jaws:

The garland that she wears, their hands must twine,

- Symonds, Ben Jonson, 198. 
Who can both censure, understand, define,

What merit is." 10

The Staple of News is referred

"To scholars that can judge and fair report The sense they hear, above the vulgar sort of nut crackers, that only come for sight." 11

Jonson deliberately chose to make supreme the things of the understanding, hence, the subordination of the love . motive throughout his dramas. We must not seek from him tender romance or beautiful love story. Perhaps he was criticised for disregard of this element, so universally dear to men and women, and was making reply in his verse in The Forest, Why $I$ Write not of Love:

"Some Act of Love's bound to rehearse,

I thought to bind him in my verse:

Which when he felt, Away, quoth he,

Can poets hope to fetter me?

It is enough, they once did get

Mars and my mother, in their net:

I wear not these my wings in vain.

With which he fled me; and again,

Into my rhymes could ne'er be got

By any art: then wonder not

That since, my numbers are so cold,

When Love is fled, and I grow old." 12

Hence, too, the lack of feeling for nature, the entire absence of that background of English fields and woods that we find in Shakespeare or Heywood. Jonson, as he him-

10 Jonson, Works, I, 148.

11 Ibid., II, 278.

12 Ibid., III, 262. 
self well knew, was not "nature's child," and we must not expect in his plays the scent of the violet by a mossy stone nor the soft lights and shadows of the Forest of Arden.

- London was the cradle of Jonson's genius, and London is the scene of all his principal comedies except Volpone, and even that is the outcome of his studies of London life. $\mathrm{He}$ knew the court and the city and could give transcripts from high life and low life. He takes us to the taverns, the private houses, the fairs, the market-places, the tradesmen's shops, the courts of justice, the theaters, the aisles of St. Paul's, and portrays to us what was said and done in the public and private life of contemporary London. The prologue to The Alchemist declares:

"Our scene is London, 'cause we would make known, No country's mirth is better than our own." 13

Jonson with keen vision noted every detail of the world around him that might contribute to the "satirically heightened picture of contemporary life" that it was the especial object of his art to produce.

Chaucer, Jonson's great predecessor in the study and portrayal of London life, was a product of the early Renaissance, and Shakespeare, who alone among contemporary writers was his equal as an observer, expressed fully and richly the spirit of the later Renaissance. Jonson himself was at every point the complete antithesis of all that the Renaissance stood for. Chaucer and Shakespeare looked on the life around them with frank wonder, wide sympathy, and spontaneous enthusiasm of heart; while Jonson's attitude was always that of careful scrutiny, judicial regard for ethical values, and unfailing self-consciousness. Where they sought simply to know and picture the world as they found it, their senses ever alert for beauty and the highest 13 Jonson, Works, II, 4. 
truth implicit in beauty, he could never free himself wholly from a bookishness that came often perilously near pedantry, an overweening regard for authority, and an attitude of assumed censorship. $\mathrm{He}$ was the chief representative of "the school of conscious effort" 14 in Elizabethan drama, with all that that implies of faults and virtues. A simple, unaffected, purely artistic picture of contemporary life we do not get from him.

As has often been pointed out, the emphasis in Jonson's comedies is on the characters rather than the plots. With his first play he gave the portrayal of character a new importance in English comedy. He seems to have conceived his persons, then invented plots to bring out their predominant qualities from as many different aspects as possible. In the typical Jonsonian comedy, as Miss Woodbridge has carefully demonstrated, the dramatis personce can always be divided into two groups, a large group of victims and a small group of victimizers, or those possessed by folly and thòse possessed of guile. ${ }^{15}$ Further, the characters do not grow or become, but remain fully determined and stationary; hence we have revelation and not development. This is a natural outcome of Jonson's regard for unity of time and his restriction of the action of a play within twentyfour hours.

Jonson's treatment of character is original and peculiar in his use of humors, and his emphasis of both superficial peculiarities and eccentricities that strike into character itself. He makes use of oddities of dress or manner, but he also goes deeper to individual twists and imperfections. "Among the English," Dryden says, "by humor is meant some extravagant habit, passion, or affection, particular to some one person, by the oddness of which he is immediately distinguished from the rest of men; which being lively and

14 Schelling, Elizabethan Drama,.I, p. XXXII.

15 Woodbridge, Studies in Jonson's Comedy, 42. 
naturally represented, most frequently begets that malicious pleasure in the audience which is testified by laughter; as all things which are deviation from the common customs are ever the aptest to produce it. . . . The description of these humors, drawn from the knowledge and observation of particular persons, was the peculiar genius and talent of Ben Jonson." 16 However, no description of humors can be better than that which Jonson himself gives in Every Man out of His Humor:

"As when some one peculiar quality Doth so possess a man, that it doth draw All his effects, his spirits, and his powers, In their confluctions, all to run one way, This may be truly said to be a humor. But that a rook, by wearing a pyed feather, The cable hatband, or the three-piled ruff, A yard of shoe-tye, or the Switzer's knot On his French garters, should affect a humor! 0 , it is more than most ridiculous." 17

Jonson is not always true to his theory here, and in spite of what he says, a humor is often a superficiality and a conscious or unconscious affectation.

He creates each of his persons, then, out of a main trait or eccentricity which rules that person in all he does and says. Such a method leads to an emphasis of the type, and has, on the one hand, the danger of personal satire in too great concreteness, and on the other. hand, that of allegory in too great abstraction. ${ }^{18}$ Into each of these extremes Jonson fell at times. Here is that same tendency to abstraction which has reappeared now and again from the moralities straight on down through English drama.

16 Dryden, Essays, ed. by Ker, I, 85, 86.

17 Jonson, Works, I, 67; Induction.

18 Woodbridge, Studies in Jonson's Comedy, 33. 
The very names of Jonson's personages are allegorical and aim to set forth a predominant characteristic. He dwells on one motive presented under many conditions, and his characters in varied relations do just what we should logically expect; thus, while they gain in emphasis and distinctness, they lose in reality and humanness, for people are mixtures of motives and by no means always act logically in accordance with what we should expect from one characteristic that we happen to know. It is a detached rather than a sympathetic view of human nature. However, we do get clear conceptions of Jonson's personages, and remember distinctly such creations as Mosca, Face, or Zealof-the-Land Busy. The types, too, are often more than local and immediate; they are universal, such as we oursêlves meet in contemporary life. Jonson attains the same kind of reality that Bunyan gives us in Pilgrim's Progress. Here we have the highest development of the allegorical method in the presentation of character. Our attention is fixed upon a quality embodied in a person rather than upon the person possessing a certain quality. For such treatment of character there is a legitimate place in literature, for we often meet people in daily life who impress us by their embodiment of self-assertion or of testiness, of jealousy or of hypocrisy, long before we feel their human personality.

What are some of the prominent types of character in Jonson's comedies? We find recurring again and again the denunciation of those who practice particular forms of vice and folly. Alchemists are satirized in the masque Mercury Vindicated as well as in The Alchemist; the worship of Mammon is exposed over and over in Volpone, The Alchemist, The Staple of News, and The Magnetic Lady; the voluptuary is painted in unsparing pictures in Volpone and The Alchemist; the hypocrisy and canting phraseology of the Puritans are held up to ridicule in Bartholomew Fair 
and The Alchemist. We find masterful portraits of the clever brainy rascal in Mosca, Face, Subtle or Brainworm; for Jonson had decided admiration and sympathy for the intellect it takes to make a thorough-going rascal. Simpletons, town and country gulls, appear in various aspects in Stephen, Matthew, La-Foole, John Daw, Fitzdotterel, Kastril, and Cokes, and these seem to have affected vividly the imagination of later playwrights. Bobadil, the supreme representative of the bragging, swaggering, disbanded soldier living by his wits, is well seconded by Tucea and Shift. The projectors, Meercraft and Engine, are the ancestors of a long line of descendants in later plays. Sir Politick Would-be of Volpone and the various intelligencers in The Staple of News represent those who make a business of distributing sensational news drawn largely from their own imagination. In Fastidious Brisk, Fungoso and Amorphus, Jonson satirizes the affected courtier and fool of fashion toward whom he always felt the most unmitigated contempt. Such are the types that recur most frequently in Jonson's comedies and most readily invite imitation on the part of his disciples and followers.

The plots are in almost all cases Jonson's own invention. He starts with the characters, prepares situations to present these as clearly and fully as possible, and then combines the situations in plots. There is much episodic humor-study in the earlier plays, where the consideration of a person's peculiarities is an end in itself. The plots are series of closely woven intrigues and skillful tricks, planned and executed by some of the characters as intriguers against the others as victims. We are sometimes bewildered by the multitude of persons, incidents and situations placed before us without a clear and unifying line of interest in Every Man out of His Humor, Cynthia's Revels, or The Poetaster. The complexity, however, as Miss Woodbridge has shown, is really on the surface and 
the underlying plan is very simple. ${ }^{19}$ The critics who censure Jonson for lack of constructive power must form their judgment from the above plays rather than from his mature work and those marvels of logical construction, Volpone, The Silent Woman, The Alchemist, and Bartholomew Fair. Here every individual trick is woven into the central line of intrigue so that we get complete unity of impression. It was Coleridge who declared The Alchemist to have one of the three best plots in existence.

The unities of time and place are regarded in that Jonson confines his action within the limits of twenty-four hours and within the boundaries of one city or town. The unity of action is perfectly preserved in Volpone or The Alchemist through all the schemes and incidents, but in Cynthia's Revels or The Poetaster is kept only by means of a uniform tone in the comic element, the centralization of comic episodes in the group of chief intriguers, and the arrangement of having all the persons know one another. ${ }^{20}$ The action is always the inevitable and strictly logical result of the motives presented in character. The plays have no central climax, no distinct rising and falling action, but push on through a network of tricks to the last act, where results are disclosed. Jonson likes to make the discovery of the trickery seem unavoidable in the latter part of the fourth act, as in Volpone, The Alchemist, or Bartholomew Fair, then on the very appearance of failure build up a new success before the final exposure.

There are several minor matters in which Jonson's usage was original and had considerable effect on other dramatists. His prologues and epilogues were marked by a novel independence of attitude toward the public and a definite announcement of moral and artistic purposes. The induction, where two or more persons discuss the play

10 Woodbridge, Studies in Jonson's Comedy, 42.

20 Ibid., 54. 
to be given and expound opinions on things in general, is a favorite Jonsonian device to forestall criticism and set forth the author's own views. Several plays have a character whose especial function is to comment on the process of the action and serve as what Miss Woodbridge calls a "demonstrator"-such are Macilente in Every Man out of His Humor and Crites in Cynthia's Revels. In the presentation of character, one personage is frequently made to describe another and prepare the way for his entrance upon the stage. This is an indirect and expository method of getting quickly before the audience prevailing characteristics by what others say rather than by what the person does and says himself. Jonson did much to make popular in English comedy of the time a number of words particularly applicable to his plots and types of character, such as "humor," "gull," "cozen," "engine," "project," or "device," and also many oaths, terms of protestation, and slang phrases, current in the street language of the day.

As to form, sometimes we find blank verse and prose almost equally divided, as in Every Man in His Humor and Every Man out of His Humor; sometimes blank verse alone, as in The Alchemist, or prose alone, as in Bartholomew's Fair; and again, the two forms combined in varying proportions. A writer's general characteristics in literary temper, construction, style, are usually repeated in his versification, and in Jonson we find no exception. His blank verse is marked by regularity and dignity, restraint and careful workmanship. His ear was atune to regularity and his lines are almost absolutely decasyllabic. The couplet is frequently used. Jonson's verse, as compared with Fletcher's, is characterized by a certain rigidity, yet he believed in freedom of phrasing and there are many run on lines. Here, his influence on the drama of his time was not great, because the tendency in dramatic blank verse was 6 
toward greater freedom and fluency, and also because comedy was more and more making use of prose. ${ }^{21}$

We have before us now the distinguishing features of Jonson's comedy of humors. The foremost innovation is the construction of personages in accordance with the theory of humors so as to bring out ruling peculiarities of conduct or character. Jonson, assuming a critical and judicial attitude, insisted on an underlying ethical intent, and gave a new emphasis and importance to moral satire against contemporary follies and vices. Further, his comedy stands for constructive excellence, constant regard for the demands of form, and masterly control of the intricacies of intrigue. A background of classical learning and a high appreciation of the rules of classic comedy, vigorous realistic portrayal of contemporary life, self-consciousness on the part of the writer, a large expository element, and an original use of prologue, epilogue, induction, and commentator on the progress of the action, are also characteristic of the Jonsonian comedy. In the following chapters we shall consider how far Jonson's immediate contemporaries and later "Sons" were influenced by these characteristics of his comedy.

21 Schelling, Eastward Hoe and The Alchemist, Belles-Lettres Series, p. XXIX. 


\section{CHAPTER II}

THE INFLUENCE OF JONSON'S COMEDY ON THAT OF HIS IMMEDIATE CONTEMPORARIES

Jonson's comrade playwrights were affected by his comedy of humors in a different way from his later disciples and "Sons." To the former, he was not a master but a fellow-worker. They watched with interest his development of a new form of English comedy, chose out and assimilated to their own use what seemed to them valuable or popularly pleasing. In their plays, therefore, we find his influence to be general rather than particular. There are several reasons for this. First of all, Chapman, Beaumont, and the others were men of independent genius who accepted no one writer as complete master; but, learning from the various dramatists of the time where each had attained greatest success, worked out individual methods of their own. The prevailing spirit of Elizabethan drama was romantic and most of Jonson's companions were too thoroughly in touch with their time to conform to any great degree to the classical ideals of Jonson's art. Indeed, "the whole spirit of the contemporary drama, its carelessness and ease, its amateurishness, its negligent construction, its borrowings and pilferings, were alien to the practice of his art, the first demands of which were originality of design, conscious literary consistency and a professional touch leading at times to mannerism." 1 Then, also, Jonson never met with uninterrupted and enthusiastic success on the popular stage, and the Elizabethan playwrights

${ }_{1}^{1}$ Schelling, Eastward Hoe and The Alchemist, Belles-Lettres Series, p. XXVII. 
were interested in producing not "closet dramas" but plays that would act and win approval from the ordinary theater audience of the day.

An original and forceful writer must necessarily influence his contemporaries to a greater or less degree, and a careful study of all the Elizabethan dramatists would probably result in the discovery of at least minor effects on most of those who wrote after Jonson had produced his first satirical pictures of contemporary life. But to trace influences is a subtle process, and the searcher is in danger of finding what he is looking for, rather than what actually exists. We shall confine our study in this chapter to the group of contemporary writers who show most clearly effects of Jonson's comedy: Chapman, Marston, Shakespeare, Beaumont and Fletcher, and Massinger and Shirley, who, though their dramatic careers came a decade later, belong here by virtue of their literary relations and the character of their work. Two anonymous plays written about 1600 also require consideration.

Although George Chapman was some fifteen years older than Jonson, yet his first comedies, The Blind Beggar of Alexandria and A Humorous Day's Mirth, were printed in 1598 and 1598 and produced about the same time as Every Man in His Humor. These men were kindred spirits, and similarities in their work are assuredly in part due to like qualities of temperament and like modes of education rather than to direct influence. Both had read deeply in classical literature and both had caught the spirit of ancient learning. As Chapman was so much the elder, perhaps Jonson was led by him to become a student in the school of Terence and Plautus. Both adopted directly and with mutual sympathy the classical ideal of comedy, its intrigue, satire and conscious restraint; so that we find them for the most part developing side by side rather than as leader and follower. Both possessed genuine scholar. 
ship, both used frequent classical allusions, both made not an emotional but an intellectual appeal, and both were characterized by conscious effort.

Jonson told Drummond of Hawthornden that Chapman was "loved of him," and their correspondence shows that they were life-long friends. In the Underwoods we find lines of warm admiration addressed to "My worthy, and Honored Friend, Master George Chapman." 2 On both Sejanus and Volpone Chapman wrote complimentary verses. In the character of Virgil in The Poetaster Jonson is supposed to portray Chapman. Henslowe's Diary records a payment of $£ 1$, Dec. 3,1597 , to Jonson for a plot; and final payment Jan. 8, 1599, to Chapman for a tragedy on "bengemens plotte." 3 Nor must we forget that they were co-authors in Eastward Hoe and together were imprisoned for references to Scotch fashions and knights considered by a sensitive Scotchman as lacking in due respect. Close personal associations and common literary tastes make us expect likenesses in the comedies of Chapman and Jonson.

In The Blind Beggar of Alexandria, ${ }^{4}$ Chapman has written a comedy of the romantic type, making use of disguise and caring little for the discrimination of character, without any satirical or ethical intent and with the use of humor only in the general early Elizabethan sense. When we turn to A Humorous Day's Mirth, we have the word humor with the Jonsonian signification, several characters conceived in Jonson's manner, a string of episodes and a series of tricks such as make up the slight plots of Every Man in His Humor and Every Man out of His Humor. The Comedy of Humors was performed by the Admiral's Men as a new play, May 11, 1597. Among the

2 Originally prefixed to Chapman's Translation of Hesiod's Works and Days, 1618.

3 Henslowe's Diary, ed. by W. W. Greg, II, 188, 199.

4 Printed 1598. Fleay gives date of first production, 1596, I, 55. 
properties mentioned are hose for Verone's son and a cloak for Labesha, these being characters in A Humorous Day's Mirth; so it would seem that this play was first acted in 1597. Accepting $\mathbf{1 5 9 7}$ as the date of the production of $A$ Humorous Day's Mirth and 1598 as that of Every Man in His Humor, we certainly have in the former a forerunner of the comedy of humors developed by Jonson. Perhaps Jonson and Chapman talked over together the idea of "humorous" characters and at the same time were seeking to work it out in plays. Lemot in A Humorous Day's Mirth, assumes the position of demonstrator and on his first appearance announces, "thus will I sit, as it were, and point out all my humorous companions." Blanuel, who is a "complete ape, so long as the compliments of a gentleman last"; Dowsecer, the young student possessed by melancholy and misanthropy; and Florilla, the Puritan wife whose vaunted Puritanism when put to the test proves to be but superficial-these are personages of the humorous type.

All Fools ${ }^{5}$ has many points of likeness to Jonson's best comedy of humors. Swinburne, it will be remembered, considers this one of the finest comedies in the English language. Here is that same excellence of reflective wisdom and practical philosophy of life that characterizes Volpone or The Alchemist, and we find again and again such utterances as these:

"But he's the man indeed that hides his gifts, And sets them not to sale in every presence;"

"The bold and careless servant still obtains, The modest and respective nothing gains;"

"Such an attendant then as smoke to fire,

Is jealousy to love; better want both

Than have both."

- Printed 1605; Fleay considers The World Run on Wheels of 1599 the same play as All Fools, I, 57. Henslowe, II, 200, 203. 
The plot is intricate and ingenious and shows that Chapman had been taking lessons of Jonson's masters, Plautus and Terence. The various schemes are remarkably well managed, and Chapman attains here what is for him unwonted success in threading his way clearly through the many tricks to produce an effective climax and a unified impression. As Ward remarks, ${ }^{6}$ there is some resemblance in the conception of the plot to that of Every Man out of His Humor in the fact that all the characters are finally gulled. The theory and practice of gulling are set forth very fully. This is put into the mouth of one of the characters :

"Nay, never shun it to be call'd a gull;

For I see all the world is but a gull;

One man gull to another in all kinds:

A merchant to a courtier is a gull;

A client to a lawyer is a gull;

A married man to a bachelor, a gull;

A bachelor to a cuckold is a gull;

All to a poet, or a poet to himself." ${ }^{7}$

Rinaldo, the eynical scholar, is the central person who sets all the other personages in motion and comments on what takes place. The description of Dariotto, the fashion-struck courtier, is in perfect accord with Jonson's scorn for that type of man and might have been written of Fastidious Brisk:

" 'Tis such a picked fellow, not a hair

About his whole bulk, but it stands in print.

Each pin hath his due place, not any point

But has his perfect tie, fashion, and grace;

A thing whose soul is specially employed

In knowing where best gloves, best stockings, waistcoats 6 Ward, II, 434.

7 Chapman, Works, ed. by R. H. Shepherd, 60; All Fools, II, 1. 
Curiously wrought, are sold; sacks milliners' shops

For all new tires and fashions, and can tell ye

What new devices of all sorts there are,

And that there is not in the whole Rialto

But one new fashion'd waistcoat, or one nightcap." 8

Gostanzo, the over-careful father, as completely deceived as the Elder Knowell in his son's knowledge of the world; Cornelius, the upstart gentleman, jealous of his wife's acquaintance as was Kitely or Corvino; Pock, the physician, who can lengthen or shorten cures at his discretion: these are personages after Jonson's own heart. The play has such a combination of prose and verse as we find in Jonson's earlier comedies, and makes frequent use of the vocabulary of roguery and gulling, "cozen," "device," "project," and the rest.

May Day and The Widow's Tears are also comedies of intrigue and of humors, and both show in plot the influence of Italian and Roman comedy. The former portrays a representative of simple gulls in Innocentio who has a great ambition to be introduced at an ordinary, and believes as he is told, that there's no prescription for gentility but good clothes and impudence. In Quintiliano, who undertakes to coach the innocent Innocentio in the ways of the world, appears again the bragging, swaggering captain. The Widow's Tears gives us the bold Tharsalio winning out by his unwavering self-confidence, but shows little if any regard for the idea of humors in the construction of character. In the last act there is a sharp satire of farcical judicial proceedings in the person of the governor, who is made to say, "in matters of justice, I am blind."

The Gentleman Usher and Monsieur D'Olive are largely romantic in plot and tone, but have also connection in their personages with the comedy of humors. The former de8 Chapman, Works, 72; All Fools, V, 1. 
scribes Pogio as the never-failing bringer of ill news, and portrays the humors of Bassiolo, the usher, who is distinguished by "overweening thought of his own worth." Monsieur D'Olive, in the person of the gentleman about town, whose name gives title to the play, affords a most successful humorous study of a combination of wag and fool. The tricks played on him are cleverly managed, and he is amusingly and completely gulled. The manners of contemporary high life are realistically portrayed in this play, and as in all Chapman's comedies, we find frequent classical allusions. The satire on Puritans and on the use of tobacco in one of D'Olive's speeches, is quite in the manner of Jonson. ${ }^{\ominus}$

The study of Chapman's comedies makes evident marked likenesses to Jonson's in the use of tricks and intrigues for effective gulling, in the production of characters of humors, in the use of classical allusions, and in a satirical portrayal of contemporary manners. Just how far these likenesses are due to similar development and how far to direct influence, it is impossible to determine.

Marston belongs with Chapman and Jonson as a scholarly poet and member of the school of conscious effort. ${ }^{10} \mathrm{He}$ too had studied carefully the classic dramatists of Roman comedy, and sought to conform to classic theories of art. His scholarship like Jonson's not only embraced ancient learning but extended also to the knowledge of his own time. In independence of the public taste of the day, assumption of censorship and invention of intrigue, Jonson and Marston are also to be closely likened. While Marston prefers to give his comedies a foreign setting, and has laid the scene of all except The Dutch Courtesan in Italy, yet they are full of realistic touches from surrounding life. That Jonson, Chapman and Marston were all three akin

๑ Chapman, Works, 123, 124; Monsieur D'Olive, II, 1.

10 Schelling, Elizabethan Drama, I, pp. XXXII, XXXV. 
in temper and training and could work together in complete harmony is proved by the successful product of their joint labors in Eastward Hoe.

Marston's personal relations with Jonson were not those of undisturbed good fellowship such as we found existing between Chapman and Jonson. The earliest connection that we know of is in the "War of the Theaters" "11 between 1598 and 1602, where Jonson and Marston were the chief combatants. Almost all of the plays involved in the controversy were written by them and are full of personal satire directed against each other. Jonson says in his Conversations that "he had many quarrels with Marston, beat him and took his pistol from him." This, as Cunningham notes, ${ }^{12}$ must have taken place before 1604 , since Eastward Hoe was acted in 1605, and before that time the poets were certainly on friendly terms again. Moreover, The Malcontent, printed in 1604, was dedicated to Jonson in most flattering words: "Beniamino Jonsonio, poetae elegantissimo, gravissimo, amico suo, candido et cordato, Johannes Marston, musarum alumnus, asperam hanc suam Thaliam, D. D." ; ${ }^{13}$ while the epilogue pays a fine compliment to him and refers to his forthcoming play The Fox. ${ }^{14}$ Marston also wrote a commendatory epigram for the 1605 edition of Sejanus. All these facts show that Marston came to have a high and hearty admiration for Jonson and his work.

Before three plays, Antonio and Mellida, The Malcontent, and What You Will, Marston introduces preliminary dialogues in inductions such as Jonson was particularly fond of using. ${ }^{15}$ That to What You Will, where three

11 Schelling, I, 475-491; and Penniman, The War of the Theaters. 12 Jonson, Works, III, 479.

13 Marston, Works, I, 197.

14 Fleay, II, 79.

15 That to The Malcontent was added in the second edition and was perhaps written by John Marston. 
poets sit upon the stage and talk together, is decidedly Jonsonian. Fleay thinks that Sir Signior Snuff, Monsieur Mew and Cavaliero Blirt signify Armin, Jonson and Middleton. ${ }^{16}$ The comedies are full not only of classical allusions but also of direct quotations from Seneca, Martial, Cicero, Ovid, and other of the Latin writers so constantly appearing in Jonson's work. Dignified, weighty reflections on life are scattered here and there, as from The Fawn:

"Thus few strike sail until they run on shelf, The eye sees all things but his proper self;" ${ }^{17}$

or from The Malcontent:

"Mature discretion is the life of state;" 18 "He ever is at home that's ever wise." 10

The satire of Chapman is marked by a frank cynicism, but that of Marston goes further even to bitterness. In What You Will one of the characters tells us to "look for the satire." In this play is described the seeming vanity of the scholar's search for knowledge:

\section{"Nay, mark, list. Delight,}

Delight, my spaniel slept, whilst I baus'd leaves,

Toss'd o'er the dunces, pored on the old print

Of titled words, and still my spaniel slept.

Whilst I wasted lamp-oil, bated my flesh,

Shrunk up my veins, and still my spaniel slept.

And still I held converse with Zabarell,

Aquinus, Scotus, and the musty saw

Of antic Donate; still my spaniel slept.

16 Fleay, II, 76, 77.

17 Marston, Works, II, 204; The Fawn, IV, 1.

18 Ibid., I, 292; The Malcontent, IV, 2.

19 Ibid., I, 310; The Malcontent, V, 3. 
Still on went I; first an sit anima,

Then, and it were mortal. $\mathrm{O}$ hold, hold! at that

They're at brain-buffets, fell by the ears amain

Pell-mell together; still my spaniel slept,

Then whatever 'twere corporeal, local, fix'd,

Extraduce; but whether 't had free will

Or no, tho philosophers

Stood banding factions all so strongly propp'd,

I stagger'd, knew not which was firmer part:

But thought, quoted, read, observed and pried,

Stuff'd noting-books; and still my spaniel slept.

At length he waked and yawned and by yon sky,

For aught I know he knew as much as I." 20

Marston satirizes the current affectation of speech, "I protest," ${ }^{21}$ the habit of promiscuous kissing in greetings, ${ }^{22}$ the curiosity for sensational news, ${ }^{23}$ the cant of Puritanism, ${ }^{24}$ and many other customs and conditions of the time. It was to Marston's didactic satire that Jonson referred in the Conversations when he said, "Marston wrote his father-in-law's preachings, and his father-in-law his comedies."

In characters, there is some slight application of the theory of humors. The Duke of Ferrara, disguised as Malevole, in The Malcontent, belongs to the type of "humorous" cynical railer found in Macilente. Sometimes Marston makes the name indicate ruling quality as Malevole, or Malheureux in The Dutch Courtesan, or Simplicius in What You Will. Coqueteur, "a prattling gull," and Cocledemoy, "a knavishly witty city companion" in The Dutch Courtesan, begin with Jonsonian conceptions but

20 Marston, Works, II, 363-364; What You Will, II, 2.

21 Ibid., II, 346-347; What You Will, II, 1.

22 Ibid., II, 46-47; The Dutch Courtesan, III, 1.

23 Ibid., II, 42-43; The Dutch Courtesan, II, 3.

24 Ibid., II, 62; The Dutch Courtesan, III, 3. 
are not developed in accord with the Jonsonian method. In The Fawn, Gonzago, the weak Duke of Urbin, who is filled with self-admiration and prides himself on his wit and shrewdness, is completely gulled and made the instrument of furthering the marriage he is seeking to prevent. The Duke of Ferrara, disguised as Faunus, assumes here the office of censor and exposes most effectively the follies and vices of the other personages. Lampatho Doria, the bitter satirist of What You Will, is identified by Marston with himself, in the way that Jonson so often uses one of his dramatic personages as a mouthpiece for his own utterances. Simplicius in this play is a simple gull who would affect the ways of the fashionable world. Thus, minor likenesses may be found between Marston and Jonson in the characters created, but on the whole, Marston conceived and developed his personages according to the romantic methods.

The Fawn ${ }^{25}$ and What You Will ${ }^{26}$ have more traces of Jonson's influence than the other comedies, not only in conception of character but also in vocabulary. The Fawn shows a marked increase in the use of Jonson's favorite oaths and terms for gulling over The Malcontent and The Dutch Courtesan, while of all the comedies What You Will has by far the greatest number of such words. This would make us expect to find What You Will written about the same time as The Fawn, perhaps a little later, afte: Marston had worked with Jonson on Eastward Hoe and had come to feel for him and his work a friendly admiration.

In scholarship, conscious effort, classicism, satire and didacticism, Marston shows resemblances to Jonson, due, it would seem, as in the case of Chapman, to like temper and training even more than to direct influence. However, in the use of inductions and in the conception of

${ }_{25}$ Printed 1606, acted, according to Fleay, 1604; Chronicle, II, 79. 26 Printed 1607, acted, according to Fleay, 1601; Chronicle II, 76. 
character, there certainly was exerted some definite influence.

Shakespeare and Jonson felt for each other warm friendship and hearty admiration. Although their purposes and methods in writing plays were very different, yet as men they were great enough and keen enough each to recognize the value and power of the other's work. The earliest trace of relationship is in the tradition that Shakespeare read Every Man in His Humor, saw its worth and recommended it to his company, thus aiding Jonson at a time of need to win his first great success on the stage. From 1598 on practically to the end of his career Jonson occasionally wrote for Shakespeare's company. ${ }^{27}$ The earliest editions of Every Man in His Humor and Sejanus include the name of Shakespeare in the lists of actors. There is a possibility that the two greatest dramatists of the age collaborated in the first version of Sejanus. Jonson in the preface to the quarto states that "this book in all numbers is not the same with that which was acted on the public stage; wherein a second pen had good share; in place of which I have rather chosen to put weaker, and no doubt less pleasing of mine own, than to defraud so happy a genius of his right by my loathed usurpation." Fleay tells us that the only known writers at this date for the King's men, who acted the play, were Wilkins, W. S., Shakespeare, and possibly Tourneur. Of these, Shakespeare is the only one that could have been the second pen alluded to, and, as he acted one of the principal parts, he may have inserted or altered scenes in which he himself appeared. ${ }^{28}$

Shakespeare stood sponsor for one of Jonson's children. Both frequented the Mermaid Tavern, and their wit combats, celebrated in Fuller's well-known description, must have been wonderful to hear. There is another tradition

27 Fleay, Chronicle History of the London Stage, 157-160.

28 Fleay, Shakespeare, 50. 
that in 1616, just before Shakespeare's death, Jonson and Drayton visited New Place in Stratford and that the three poets had a merry meeting. ${ }^{29}$ Jonson's own attitude toward his fellow-poet is fully expressed in the Lines prefixed to the folio of 1623, where with enthusiastic and also discerning praise he addresses "My Shakespeare," "star of poets," "Sweet Swan of Avon," "the applause, delight and wonder of our stage." What he writes of "my beloved Master William Shakespeare" could come only out of years of intimate association and affectionate admiration. Again, in the Timber, he tells us that he "loved the man," and honored his memory "on this side idolatry."

The question here is, do Shakespeare's comedies show any reflex influence of Jonson's theory of humors? Shakespeare's genius was highly adaptable. He had not, like Jonson, fixed dramatic theories in accordance with which he consistently contructed his plays; but, observant of all artistic forms and methods of the time, he responded quickly to the popular taste or interest of the moment, adopted and assimilated to his own use whatever seemed of value in making a good play and pleasing the public. About 1600, Jonson's comedy of humors and Middleton's comedy of bare, even bitter, realism were winning great applause on the Elizabethan stage. Surely it is not farfetched to discover traces of Middleton's influence in the tone of Measure for Measure and All's Well that Ends Well. So also, in several groups of irregular humorists and in one character of All's Well that Ends Well Shakespeare does show the effect of Jonson's conception of humor.

Koeppel indicates three places in Jonson's comedies in which he considers the situations to owe something to the influence of Shakespeare: in The Case is Altered, the re29 Halliwell-Phillips, Outlines, 1898, II, 70. 
lation of Jaques and Rachel, the girl's flight to her lover, and the miser's lament over his gold and girl, as bearing direct relation to The Merchant of Venice; in The Poetaster, the love-scene between Ovid and Julia, as a Romeo and Juliet situation; in Epicone, the duel episode between Sir John Daw and Sir Amorous La-Foole as reminiscent of that in Twelfth Night between Sir Andrew Aguecheek and Viola. ${ }^{30}$ Miss Henry in her edition of Epiccene accepts Twelfth Night as a source of Jonson's play and carefully traces likenesses between the gulling of Daw and La-Foole by Truewit and the duel between Sir Andrew and Viola as urged on by Sir Toby. ${ }^{31}$ However, as Dr. Schelling points out, Jonson was not in the habit of borrowing ideas from contemporary dramatists, ${ }^{32}$ and these parallels are far-fetched and decidedly doubtful.

Six plays written by Shakespeare between 1597 and 1602, Henry IV, Parts I and II, Henry V, Merry Wives of Windsor, Twelfth Night and All's Well that Ends Well, show the effects of Jonson's conception of humor. It was Shakespeare, if we are to trust the old tradition, that read Every Man in His Humor, understood the greatness of its basic idea, and prepared the way for its production in 1588 . I Henry IV was acted in 1597, II Henry IV in 1598, Every Man out of His Humor in 1599, and Henry $V$ in 1599. Thus the three historical plays coincide in time with the two humor plays of Jonson. The comedies, Merry Wives, Twelfth Night and All's Well, are dated between 1598 and 1602 , when the humor idea was at the height of its novelty and popularity.

In Henry IV Falstaff and his followers are unlike any previous group of Shakespeare's characters. Touched as

30 Koeppel, Quellen Studien, 2, 5-6, 11-12.

81 Henry, Aurelia: Epicœne, Yale Studies in English, XXXI, 1906 ; Introduction, XXXV-XL.

32 Schelling, I, 540. 
they are, humanized as they are, by Shakespeare's individual genius, yet humorous are they also in their conception and portrayal. Falstaff, himself a "trunk of humors," forms the center of a group which, while the individual members change somewhat, remains a source of keen interest and enjoyment through Henry IV, Merry Wives of Windsor and Henry V. Falstaff, " not only witty in myself but the cause that wit is in other men," "huge bombard of sack," and "vanity in years," believing "the better part of valor is discretion," troubled with "the disease of not listening" when accusations are brought against him, and having "more flesh than another man and therefore more frailty," is not only the possessor of humors but also the means of calling forth humors in others. Prince Henry, away from the court in association with Falstaff, declares: "I am now of all humors, that have showed themselves humors since the old days of goodman Adam to the pupilage of this present twelve o'clock at midnight." ${ }_{33}$

Poins and Peto, the Prince's attendants, Gadshill, and, above all, Bardolph with his big purple nose, "Knight of the burning lamp," in I Henry IV take part in the escapades, sack festivities and wit combats of which Sir John is the leader. Ancient Pistol takes the place of Gadshill in II Henry IV, and here also are introduced Shallow, an old acquaintance of Sir John's earlier years and now a country justice whose humor is to prate of the wildness of his youth, and Shallow's cousin, the silent Silence. This cousin is replaced by another, Slender, the simple, self-conceited and yet fearful wooer of Anne Page, in Merry Wives of Windsor. Bardolph and Pistol reappear and Falstaff has a new follower in Corporal Nym. His humor is a humor and his comment on every possible occasion is "that's the humor of it," "that's my humor," or "I thank thee for that humor." Sir Hugh Evans, the 33 I Henry IV, II, 4. 
pedantic Welsh parson, and Dr. Caius, the hot-tempered French physician, are also humorists. Lieutenant Bardolph, Ancient Pistol and Corporal Nym survive to follow the King to the French Wars in Henry $V$. They still possess their individual humors, and of their old leader Falstaff, who has just died, they speak with regret and affection. Nym and Bardolph are hanged for thieving and Pistol alone returns from France, old, weary, and lonely without his former companions. Henry $V$ has a new group of humorists in Fluellen, the pedantic but loyal Welshman, Macmorris, the valiant quick-tempered Irishman, and Jamy, the slow solid Scotchman, over all of whom is placed the practical Englishman, Captain Gower.

Sir Toby Belch, Sir Andrew Aguecheek, and Malvolio of Twelfth Night are most successful examples of the use of humors in the creation of character. Sir Toby, with his weakness for quaffing and drinking and his superficial learning, has yet a keen wit and a shrewd insight into his fellow-sinners. Sir Andrew Aguecheek has studied fencing, dancing, and bear-baiting, and above all else, can "cut a caper"; but, impressed by Sir Toby's show of learning, he wishes he had studied the tongues and arts. His importance to Sir Toby lies in the fact that he has three thousand ducats a year and furnishes that impecunious, fun-loving old toper with opportunity to replenish his own empty purse and to have some sport by the way. Sir Andrew "besides that he's a fool, he's a great quarreler; and, but that he hath the gift of a coward to allay the gust he hath in quarreling, 'tis thought among the prudent he would quickly have the gift of a grave." ${ }_{34}$ Malvolio is "sick of self-love" and possessed by "the spirit of humors intimate." Maria, a "noble gull-catcher," sets out to "gull" him and "make him a common recreation." As a result of her device, he appears in yellow stockings, 34 Twolfth Night, I, 3. 
cross-gartered, and with a wonderful smile such that "he does smile his face into more lines than are in the new map, with the augmentation of the Indies." 35

In Parolles of All's Well that Ends Well we have a character very different from most of Shakespeare's personages and like many of Jonson's. He is "a most notable coward, an infinite and endless liar, an hourly promise-breaker, the owner of no one good quality." 36 Shakespeare intends his name to indicate his ruling characteristic. He is nothing but words, "there can be no kernel in this light nut, the soul of this man is his clothes." ${ }_{37}$ Parolles realizes that his tongue prattles him into all sorts of troubles, and as one of the other characters who hears him talking to himself says, "the wonder is that he should know what he is and be that he is." A plot is made and effectively carried out by which his folly and falsehood are mercilessly exposed. The comic portrayal here is not sympathetic, as is usual with Shakespeare, but wholly satirical.

Shakespeare grasped the idea of humors and applied it, not rigidly and lifelessly, as did many of the later dramatists, but sympathetically and humanly, vitalizing the theory by the power of his own marvelous genius. He was not beguiled from his general realistic and romantic manner by Jonson's conception of comedy, but he did try in Henry IV, Henry V, Merry Wives of Windsor, Twelfth Night and All's Well that Ends Well the method of humor in the presentation of individual characters.

Two anonymous plays, The Fair Maid of the Exchange, and Every Woman in Her Humor, both, according to Fleay, acted in 1602, are best considered here before we take up the study of Beaumont and Fletcher. The title-

35 Twelfth Night, III, 3.

36 All's Well That Ends Well, III, 6.

37 All's Well That Ends Well, II, 5. 
page of The Fair Maid of the Exchange advertises the play as presenting "the Humors of the Cripple of Fanchurch"; and the father of the heroine is characterized in the dramatis personce as "an humorous old man"; yet in reality the only personage created according to the method of humor or caricature is Bowdler, "an humorous gallant," "an humorous blossom," "a fond humorist, parenthesis of jests, whose humor like a needless cypher fills a room." He puts on an "antick garment of ostentation," takes especial pride in his "caper and turn o' the toe," and pretends that all the maids he meets are prone to love him, when in truth he himself is afraid to speak to them and arouses their merry ridicule. The cripple of Fanchurch undertakes and effects his "purgation."

Every Woman in Her Humor is an example of the height or depth of crude undiscerning imitation, and was written by some author who knew little of human character and less of dramatic construction. The title was plainly suggested by Jonson's first comedy of humors. The plot is slight, consisting of little more than a series of situations strung together on a slender thread of accidental connection, and lacking the underlying unity of the seemingly careless plots of Jonson's earlier plays. The scene is laid in Rome, perhaps, if the play was produced in 1602, in imitation of The Poetaster acted in 1601; but the stupid anachronisms bear evidence that the author possessed none of Jonson's regard for accuracy. Some of the characters are direct imitations of Jonsonian personages. Graccus and Acutus at the beginning of the play, like Asper and Macilente in Every Man out of His Humor, discuss "this impious world." Acutus wears "a vizard of melancholy" and rails against prevailing follies and vices. This description of him by Tully recalls the praises of Crites in Cynthia's Revels: 
"his spirit is free as air,

His temper temperate, if aught's uneven, Fis spleen weighs down towards lenity; but how Stirred by reproof! Ah, then he's bitter and like His name Acute, vice to him is a foul eyesore, And could he stifle it in bitterest words he would, And whoso offends to him is parallel, $\mathrm{He}$ will as soon reprove the cedar state As the low shrub." 38

Getica is even more foolishly concerned for her dog than is the like humorist Puntarvolo for his in Every Man out of His Humor, and Acutus longs to teach it "the trick of the rope." The talkative, fussy, but honest Host is ever ready with the proverbial expression "dun's the mouse" or "the mouse shall be dun." The Hostess constantly complains of her busy life, yet seems to be happy in it and finds recreation in a lively gossip. The citizen's wife, an Elizabethan Wife of Bath, who has buried six husbands and thinks there is good hope that she may have as many more, loudly resents the new statute which forbids a woman to marry again until two months after her husband's death. The portraiture of these vigorous lower-class personages is the best part of the play. In dramatic value, Every Woman in Her Humor ranks among the comedies of humors of some of Jonson's later followers rather than among those of his immediate contemporaries.

With Beaumont and Fletcher we must at the very beginning remember that they stand fundamentally as representatives of the romantic school. They were influenced in their work as a whole far more by preceding dramatists of that school than by the classical and conscious art of Jonson. However, they were first of all practical play$\mathrm{V}, \mathrm{l}$.

38 Bullen's Old Plays, vol. IV, 372; Every Woman in Her Humor, 
wrights who aimed to please the public taste of the time and to make plays that would act; so they chose out from the methods of other writers what suited their purposes. Their own method was eclectic, and they found it possible in their earlier days to get valuable instruction from Jonson in matters of construction, humorous characterstudies and versification. Especially is this true of Beaumont who began writing plays decidedly under the influence of Jonson.

Beaumont had gained the friendship of Ben Jonson as early as 1607 , for in that year we find him addressing verses that show good critical judgment "To my Dear Friend, Master Ben Jonson, upon his Fox." Again, in 1609 he wrote commendatory verses on The Silent Woman and in 1611 on Catiline. However improbable may seem Dryden's statement that "Beaumont was so accurate a judge of plays, that Ben Jonson, while he lived, submitted all his writings to his censure, and 'tis thought, used his judgment in correcting if not contriving all his plots," ${ }^{30}$ yet it is certainly based on a tradition of close relationship. Beaumont's Letter to Ben Jonson with its famous description of the gatherings at the Mermaid and high compliment to Jonson's wit, reveals clearly the younger man's admiration and enthusiasm for his older friend. ${ }^{40} \mathrm{He}$ is ready there to

"Protest it will my greatest comfort be To acknowledge all I have to flow from thee."

The short poem in which Jonson makes answer to this letter is full of cordial appreciation and affectionate regard:

"How I do love thee, Beaumont, and thy muse That unto me dost such religion use!

so Dryden, Essays, ed. by W. P. Ker, I, 80.

40 Jonson, Works, I, CXIV-CXV. 
How I do fear myself, that am not worth The least indulgent thought thy pen drops forth! At once thou mak'st me happy and unmak'st; And giving largely to me, more thou tak'st! What fate is mine, that so itself bereaves? What art is thine, that so thy friend deceives? When even there, where most thou praisest me, For writing better, I must envy thee." ${ }^{41}$

Jonson's remark to Drummond "that Francis Beaumont loved too much himself and his own verses" is not at all destructive of the above evidence of warm friendship and mutual admiration.

Pleasant personal relations also existed between Jonson and Fletcher, and expressions of good-will were exchanged. Fletcher wrote verses on The Fox in 1607 and on Catiline in 1611, Jonson being called in the latter, "dear friend." Brome says that Jonson was proud to call Fletcher "son" and

\section{"Swore he had outdone \\ His very self." ${ }^{42}$}

When Fletcher's Faithful Shepherdess failed to receive the recognition and praise it deserved, Jonson wrote some lines of warm admiration, prophesying for his friend that his poem

\section{"shall rise}

A glorified work to time, when fire

Or moths shall eat what all these fools admire." ${ }_{43}$

Later, he told Drummond "that next himself, only Fletcher and Chapman could make a mask." Dyce sug-

41 Jonson, Works, III, 235.

42 Beaumont and Fletcher, Works, I, 92.

43 Jonson, Works, III, 291. 
gests that Beaumont and Fletcher were perhaps first brought together by Jonson. ${ }^{44}$

As playwrights, Beaumont and Fletcher learned most from Jonson in ideals of constructive excellence. In management of detail with constant reference to the entire plot and regard for complete unity of impression, in careful preparation for important characters before their entrance, in clever invention of tricks and skillful conduct of intrigue, they show that they were his quick and intelligent pupils. Such plays as The Woman Hater, The Scornful Lady, Rule $a$ Wife and Have $a$ Wife, The Tamer Tamed, or The Humorous Lieutenant, include in their plots tricks equal in wit and ingenuity to those invented by Jonson and probably for conception and management in part due to his teaching. In The Scornful Lady, it is of interest to note the knowledge of Plautus and Terence shown in a quotation from the former and a situation from the latter. The Four Triumphs and The Knight of the Burning Pestle have inductions, and the latter has also a running comment in dialogue form within the play. Such description as that which prepares us for the entrance of Lazarillo and Lucio in The Woman Hater is frequently found in Jonson. The censor and satirical commentator on personage and action we find also in The Woman Hater-probably written by Beaumont and showing more than any other play direct Jonsonian influence.

There are characters of humors in a number of plays. In The Woman Hater Lazarillo, "the hungry courtier," is in pursuit of a fish's head famed as most rare and delicate; Gondarino is almost a monomaniac in his hatred of womankind; Lucio, a simple lord, is possessed with the idea that he has great powers of statesmanship; a mercer is moved by an overwhelming desire to ape scholars. The Scornful Lady portrays the humor of "the scornful lady" as an at44 Beaumont and Fletcher, Works, ed. by Alex. Dyce, I, 12. 
titude of scorn toward all men; that of her waiting-woman, the pursuit of young lovers; and that of a widow, the acquisition of a knight. Merrythought in The Knight of the Burning Pestle is forever merry in the midst of all sorts of trials and perplexities; Humphrey is an ordinary simple gull; and Ralph, who of course owed his creation to Don Quixote, has, we are told, the "humor" of going on adventures. Bessus, ${ }^{45}$ the braggart coward in A King and No King, may have been suggested in part by Bobadil, but certainly lacks the individuality and personal eccentricity that make that personage amusing and interesting throughout. The character of the lawyer in The Little French Lawyer is conceived in Jonson's spirit. La Writ having been forced by a stranger to take part as a second in a duel and having won a victory, becomes so possessed with the love of fighting that he deserts his business and sets up as a regular duelist, being cured of his whimsical humor at length by means of a trick played on him. The person who gives title to The Humorous Lieutenant passed rapidly from the humor for fighting when he was sick to the humor of cowardice when he was well. Various tricks are devised and carried through to purge him of his humor.

Beaumont and Fletcher sometimes give names to indicate the reigning quality of character as "the scornful lady" and Merrythought or Lady Heartwell, Lovegood and Harebrain in Wit Without Money. This method of course goes back to the allegorical element in the miracle plays and moralities, but it was given new impetus by Jonson. There is, however, a marked difference in the treatment of types by Jonson and by Beaumont and Fletcher. While he seeks to emphasize the individuality of his representation of the type, they dwell almost always upon the class qualities.

The spirit of satire and the definite purpose of ridiculing ${ }^{45}$ Koeppel compares Bessus to Falstaff, Quellen-Studien, 44, 45. 
folly we find only in the earlier plays, The Woman Hater, The Scornful Lady and The Knight of the Burning Pestle, all ascribed in large part to Beaumont. In the first of these we are plainly told that the desire is to see the woman hater "purged" and a "cure" wrought upon him. The description of court-life and of theater-going in this same play contains keen and effective satire of contemporary conditions. ${ }^{46}$ The Scornful Lady shows how the scornful lady and also a usurer were turned from their follies. The Knight of the Burning Pestle is throughout a satire on the city and on the extravagances of the earlier stage. The dialogue between the citizen and his wife has all Jonson's vivid realism.

Koeppel remarks the transformation of Leon in Rule a Wife and Have $a$ Wife from a meek silent creature before marriage to a masterful lord immediately afterward, able to talk and act boldly, as similar to that of Epicœne in The Silent Woman. ${ }^{47}$ The same writer notes further that the astonishment of the husband over the sudden independence and self-assertion of his newly married wife in The Tamer Tamed seems a reminiscence of the perplexity and amazement of Morose. ${ }^{48} \mathrm{He}$ does not call attention to the fact that the name of the rich old man in this same play who is seeking a young wife is Moroso. Fletcher's verse is essentially different from Jonson's, but Beaumont's, as has been often remarked, shows many of the same characteristics. Beaumont adheres strictly to the metrical scheme of regular decasyllabic lines, uses largely the masculine internal caesura, has free dignified phrasing with many run on lines. In his blank verse Beaumont certainly followed Jonson as master and teacher.

What are the conclusions as to the influence of Jonson

46 Beaumont and Fletcher, Works, I, 99; The Woman Hater, T, 3. 47 Koeppel, Quellen-Studien, 116.

48 Ibid., 90. 
on Beaumont and Fletcher? That both were influenced to a consideraable degree in dramatic construction, and to a limited extent in conception of characters; that Beaumont was more deeply impressed than Fletcher, really began his work under the tutelage of Jonson, caught from him the spirit of dramatic satire, and learned much in the art of writing blank verse.

There is no direct evidence that Massinger knew Jonson or was personally associated with him, but it is altogether likely, from Massinger's relation of friendship and co-authorship with Fletcher and from his prominence among the London playwrights of Jonson's later life, that he was sometimes present at the meetings of the Apollo Club, and that he was impressed by the forceful seriousness of Jonson's attitude to life as well as by the excellence of his art. Massinger went up to London in 1606 or 1607, and although we have no mention of his name as a dramatist until 1621, we know that during this interval of time he was writing plays and learning the business of the stage. That in some matters he was a pupil of Jonson, a study of his plays clearly shows. Like Beaumont and Fletcher, he was by no means a plagiarist or imitator, but he understood his art and with ready ease and remarkable facility could learn from many sources and adapt what he learned to the making of plays that would act.

He seems to have been affected most by Jonson in construction and moral satire, but also to have felt his influence in the portrayal of contemporary life and in the conception of character. Of course we must certainly remember that Middleton's influence as well as Jonson's was decidedly at work in picturing contemporary life, drawing character, portraying manners, and it is impossible to determine absolutely the exact limits of the influence of each on the younger dramatists. The plays that relate Massinger's art most definitely with Jonson's are The City 
Madam and A New Way to Pay Old Debts, produced according to Fleay, about 1619 and 1621 , $^{49}$ and ranking high among English comedies of manners. In both we find great ingenuity and skill in weaving and then untangling the intricacies of the intrigues. Each single incident, each separate trick, is made to take its place in preparing with sureness for the final outcome. Each detail of description or action serves its part in unfolding and developing the characters. In his mastery of construction and sense of artistic logic, Massinger undoubtedly received valuable instruction from Ben Jonson.

The City Madam and A New Way to Pay Old Debts present realistic transcripts from contemporary life and aim to exhibit and satirize the follies and vanities of the day. Massinger here, like Jonson, assumed an attitude of censorship toward society. In his wealth of observation of both London and provincial life, and in his keen and telling satire of social abuses, he fell not greatly below his master. He would

"scourge a general vice,

And raise up a new satirist." "so

Not only in general didactic tone, but also in direct moral utterances, generalizations, maxims and proverbs, he proves himself always a strict and conscientious moralist and never makes us feel, as Beaumont and Fletcher sometimes do, that all moral principles are in a state of uncertain solution.

Massinger follows the example set by both Jonson and Middleton of giving names descriptive of their owners, in The City Madam and A New Way to Pay Old Debts. In the former, we have Sir John Frugal, the economical merchant; Mr. Plenty, the wealthy country gentleman; Stargaze, the

49 Fleay, Chronicle, I, 214, 225.

so Massinger, Best Plays, I, 475; The City Madam, IV, 4. 
astrologer; Holdfast, the penurious steward; Goldwire and Tradewell, the middle class tradesmen. The same method is used in A New Way to Pay Old Debts with Justice Greedy, whose one aim in life is to satisfy his passion for eating; Marrall, who, we are told, "marred all"; Sir Giles Overreach, whose previous eareer has been one of unbroken success in overreaching; Furnace, the cook; Watchall, the porter; Wellborn, a young man of good birth (a name used by Jonson in Bartholomew Fair); Amble, the usher (Ambler is the usher in The Devil Is an Ass); and Order, the steward. The characters are built up on the basis of one predominant quality, and like Jonson's comic types are subject to the faults of exaggeration and caricature. However, there is a difference of treatment in that Massinger dwells with Beaumont and Fletcher upon the common characteristics of the type, instead of seeking with Jonson the subtle individual quality of the particular representative of the type. A comparison of the two gluttons, Justice Greedy and Zeal-of-the-land Busy, makes manifest this difference.

James Shirley, although born in the last years of the sixteenth century and considerably younger than the preceding dramatists, yet belongs in the same group on account of his personal connections and the character of his work. He collaborated with Chapman and Fletcher in writing plays during the latter parts of their careers, prepared the prefatory matter for the Beaumont and Fletcher folio, worked side by side with Massinger in developing the later comedy of manners based on the combined methods of Jonson and Middleton, and was addressed as "judicious and learned friend" by Massinger who also called himself "a modest votary at the altar of thy muse." In Shirley's plays, as in Beaumont's and Fletcher's and Massinger's, the romantic element is in the ascendancy, but in the eclecticism of all these playwrights there was a place for the 
comedy of manners and of humors. Shirley, like Massinger, was a pupil of both Jonson and Middleton in comedy of manners. Here we are especially concerned with evidences of Jonson's influence.

Shirley, too, must have known and enjoyed part in the gatherings at the Devil Tavern. In one of his plays a servant is told to "run to the Devil" for wine." As a young student of playwriting, he must have been impressed by the originality and force of Jonson's work, and in his own first attempt, Love Tricks, shows unmistakably who was one of his teachers. In the dedication of The Grateful Servant, he speaks with honor and admiration of "our acknowledged master, learned Jonson." William Habington, in commendatory verses to Shirley, associates his name with Jonson's :

"'and when his muse expires,

Whose English stains the Greek and Latin lyres,

Divinest Jonson, live to make us see

The glory of the stage reviv'd in thee."

In the writing of masques as well as comedies of manners Shirley was influenced, and in court entertainments succeeded largely to Jonson's popularity and success, producing The Triumph of Peace, one of the greatest masques of the time. In this, the antimasque especially recalls Jonson, in the presentation of six projectors, such as he so effectively satirized in The Devil Is an Ass, and of the dotterels whose foolish bent for imitation appealed to him and gave name to the gulled Fitzdotterel in the same play. The talk of the citizens in The Triumph of Peace resembles that in The Masque of Augurs or Neptune's Triumph.

Such influence as we find in this masque, in character that of reminiscence and general recollection, is exerted also in the comedies. Shirley is a happy and original com-

51 Shirley, Works, ed. by Alex. Dyce, I, 383, The Wedding, II, 1. 
bination of what had gone before him and he certainly learned somewhat from Jonson. In originality and variety of plots Shirley excelled, and here he followed the example of Jonson in turning from the use of old plays and novels to invent new situations. Further, his plots are closely knit, unified, and in regard for constructive detail, directly or indirectly he had benefited by Jonson's work.

The pictures of London life given in such plays as Love Tricks, Hyde Park, The Lady of Pleasure, The Ball, The Gamester, The Example, The Witty Fair One or The Wedding, are more attractively realistic than those we get from Middleton's plays. They show a deeper insight into the human significance of a conversation, situation and action, a more thoughtful and understanding grasp of underlying meaning. Much of the difference is due to Shirley's own temperament, but perhaps in some part also to Jonson's attitude. Shirley yields neither to the absolute realism of Middleton nor the didactic satire of Jonson, but learning from both, gives pictures in some ways truer than those we get from either of the others. There is in Shirley a moral sanity and ethical sense that we oftentimes find lacking in Middleton, and while here again we must ascribe much to Shirley's own well-balanced nature, yet perhaps some influence was exerted also by Jonson's strong ethical bent.

Several prologues are written in a Jonsonian tone of independence and even arrogance toward the public. Compare this from the prologue to The Example:

"Nay, he that in the parish never was Thought fit to be o' the jury, has a place Here, on the bench, for sixpence; and dares sit, And boast himself commissioner of wit: Which though he want, he can condemn with oaths, As much as they that wear the purple clothes, 
Robes, I should say, on whom, i' the Roman state, Some ill-look'd stage-keepers, like lictors wait,

With pipes for fasces, while another bears

Three-footed stools instead of ivory chairs," 82

with this from the prologue to The Staple of News:

(the maker) "prays you'll not prejudge his play for ill, Because you mark it not, and sit not still;

But have a longing to salute, or talk

With such a female, and from her to walk

With your discourse, to what is done, and where,

How, and by whom, in all the town but here.

If that not like you that he send to-night, 'Tis you have left to judge, not he to write." ss

Again, in the prologue to The Duke's Mistress, we meet with just such an utterance as we have become familiar with in Jonson:

"We do observe the general guests to plays ; Meet in opinion of two strains that please, Satire and wantonness; the last of these, Though old, if in new dressing it appear, Will move a smile from all,-but shall not here.

Our author hath no guilt of scurril scenes. For satire, they do know best what it means, That dare apply; and if a poet's pen Aiming at general errors, note the men, 'Tis not his fault: the safest cure is, they That purge their bosoms, may see any play." ${ }_{54}$

Several plays have situations or devices that recall Jon62 Shirley, Works, III, 282.

s3 Jonson, Works, II, 277.

s4 Shirley, Works, IV, 191. 
son. In Love Tricks, the mock duel, described so boastfully by Bubulcus, has a marked resemblance to the account given by Fastidious Brisk of his supposed victory in Every Man out of His Humor. ${ }^{55}$ The passage from Love Tricks is worth quoting, so much is it in Jonson's manner:

"Bubulcus. We threw our doublets off, to shew we had no coat of mail, or privy shirt upon us, against the laws of dueling: in fine, I bid him say his prayers.

Antonio. 'Twas well thought upon; and what did you? $B u b$. I let them alone, for I knew I should kill him, and have time enough to say them afterwards at my leisure.

Hilaria. When he had prayed, what then?

$B u b$. When he had said his prayers, he thought upon it, and let fall words tending to reconcilement. On my conscience, he would have asked my forgiveness, but I stood upon my honor, and would fight with him, and so we stood upon our guard-but not a word of fighting, if you love me.

Ant. Oh, by no means: but when did you fight?

$B u b$. I'll tell you; Antonio, when he saw no remedy, but that I would needs fight with him, and so consequently kill him, made a desperate blow at my head, which I warded with my dagger, better than he looked for, and in return, I cut off his left hand; whereat amazed, and fainting, I nimbly seconded it, as you know I am very nimble, and run my rapier into his right thigh, two yards.

Hil. Then you were on both sides of him?

Ant. Your rapier? Did you not say your weapons were long swords?

$B u b$. But mine was both a sword and rapier, there 'tis-

55 Schelling, Elizabethan Drama, II, 287. Compare with Jonson, Works, I, 119-120, Every Man Out of His Humor, IV, 4. 
but not a word of fighting, as you love me. Well, not to weary you with the narration of the innumerable wounds I gave him, I cut off every joint from his toe upwards, to his middle; by these hilts, now, you may believe me; there ended Antonio, my rival. Judge, judge now, whether Bubulcus be valiant or not-but not a word of fighting, as you love me; let it die. Ant. "Twas very valiantly done." 56

The School of Compliment in this same play brings together a group of humorous characters such as Jonson assembled in the Ladies Collegiate of The Silent Woman, the news-collecting agency of The Staple of News, or the school of cosmetics and behavior in The Devil is an Ass. The situation of the old man Rufuldo married to a man disguised as a woman, and, finding himself tied to a masterful shrew, in the end thoroughly glad to be freed from his burden, may perhaps be a reminiscence of The Silent Woman. The likeness of the passage in The Young Admiral where the foolish Pazzarello is introduced to the supposed enchantress who is to make him invulnerable in battle, to that in The Alchemist where Dapper is taken into the presence of the "fairy" whose favorite he has been assured he is, has been noticed by Gifford. ${ }^{57}$

When we turn to characters, we find a number ereated on the basis of humors or seemingly reminiscences of Jonson. In Love Tricks, Bubulcus, an "exact piece of stolidity" comes to the school of compliment to "have a delicate speech" for his lady-love, and "a powdering speech" for his rival, whom he would kill without danger of the law, and so with words. He gives boastful account of his prowess in dueling and like Shift with his thefts in Every Man out of His Humor later confesses to base cowardice

s6 Shirley, Works, I, 74-75; Love Tricks, IV, 6.

57 Ibid., III, 145; The Young Admiral, IV, 1. 
and lying with "thinking to have got himself some credit," as Shift "to get" himself "a name." Orlando Furioso, who comes to learn to "roar" and quarrel, recalls Kastrill, the angry boy in The Alchemist. Shirley makes many references to the roarers of the time, satirized by Jonson not only in The Alchemist but also in The Silent Woman as the "terrible boys" and in The Staple of News as the "canters." Sir Valentine Wantbrain, who has been newly put into commission for the peace and comes to the School of Compliment to have drawn up his first charge to the jury; the countryman who brings his son Oaf to be made a scholar and a courtier; and Ingeniolo, the justice's clerk, who wishes to be taught to speak his passion of love in blank verse-these are "humorous" conceptions, though slightly developed.

Brains in The Wedding, whose pride it is that he has never been overreached in any action, whose "nourishment runs upward into brains" and who boasts that he "was never yet cozened," seems to be a reminiscence of Brainworm. Sir Solitary Plot in The Example, pointed out by Dyce as an imitation of Jonson,"s8 believes "the world is full of plots" and spends most of his time in solitude, planning methods of precaution. The suggestion for Jack Freshwater in The Ball, Gifford thinks was furnished by Puntarvolo in Every Man out of His Humor. ${ }^{59}$ The likeness between Freshwater's account of marvelous experiences on his supposed return from travel and Puntarvolo's fantastic preparations for a journey is certainly not very evident; but the conception of the character probably developed in Shirley's mind under the influence of Jonson's personages. Pazzarello in The Young Admiral, who, duped to believe that he has been made invulnerable, waxes ex-

58 Shirley, Works, I, Introduction, XXX.

59 Ibid., III, 3. 
ceedingly valiant; Caperwit, the poetaster in Love in a Maze, and Sir Gervase Simple of the same play-

\section{"one that has}

But newly cast his country skin, come up

To see the fashions of the town, has crept

Into a knighthood, which he paid for heartily

And in his best clothes, is suspected for

A gentleman;" "80

and Orseolo, who gives name to The Humorous Courtier and whose humor is to rail against women,-all are conceived in Jonson's manner. The influence of Jonson is manifested in the fundamental idea of a prevailing humor or bias much more than in the method of development. Shirley does not, as Jonson, take the trouble to present the humor under many different aspects and in many relations so as to produce a many-sided study.

Here, as with the other dramatists of the group studied, it is impossible to state definitely the exact limits of Jonson's influence. Shirley's first play was plainly modeled in plot, characters, satirical pictures of contemporary life and vocabulary on Jonson's comedy. In later plays, careful logical construction manifests a permanent effect of the teaching Shirley had had. Now and then appears a character conceived according to the theory of humors. Several prologues are Jonsonian in tone. An occasional situation, device or expression, seems reminiscent of Jonson's plays. Shirley was no imitator, no slavish follower, but an original and inventive playwright who could take lessons from a master and then apply them with independence and power.

oo Shirley, Works, II, 277; Love in a Maze, I, 1. 


\section{CHAPTER III}

NATHANIEL FIELD AND RICHARD BROME IN RELATION TO JONSON

We turn now to the younger dramatists who were distinctively "Sons of Ben," who consciously and definitely took the attitude of disciples toward the master of the comedy of humors, fully acknowledged his authority and sought to follow closely in the paths marked out by him. In this group we shall study the comedies of Nathaniel Field, Richard Brome, Thomas May, Robert Davenport, Thomas Randolph, Shakerley Marmion, William Cartwright, Jasper Mayne, Henry Glapthorne, Thomas Nabbes, Sir Aston Cockayne, William Cavendish, Earl of Newcastle, and Sir William Davenant. First of all, we shall consider Field and Brome, to whom Jonson stood in the direct relation of teacher to pupils. These had especially close personal associations with him and gained the advantage of being personally instructed by him in the art of making plays, of learning their eraft under his immediate supervision.

Nathaniel Field was an "actor playwright" and began his connection with the stage as a member of one of the boy companies prominent about 1600, the Children of the Chapel, known in the reign of King James as the Queen's Revels. He was chief actor in three of Jonson's plays acted at Blackfriars by the Chapel Children: Cynthia's Revels in 1600, Poetaster in 1601, Epiccene in 1609. Again, in 1614 he was chief actor in Bartholomew Fair produced at the Hope by the Lady Elizabeth's Men. ${ }^{1}$ It is in the last play that Jonson pays him the high compli-

1 Fleay, Eng. Stud., XIII, 1889. 
ment of associating his name with that of Burbage, and praises him as the best actor in his company :

\section{"Cokes. Which is your Burbage now? Leatherhead. What mean you by that, sir? Cokes. Your best actor, your Field?"'}

We can imagine that an additional appeal was made to Jonson's sympathies by the fact that Field was one of the boys kidnaped by Nathaniel Giles, Master of her Majesty's Chapel, in abuse of his privilege of taking young boys to sing in the royal chapels, and pressed into enforced service as an actor in the company of which Giles had the management, the Children of the Chapel. ${ }^{3}$ When carried off, Field was a pupil at Westminster School, and only thirteen years old at the time he took the chief part in Cynthia's Revels. ${ }^{4}$ Evidently Jonson pitied the boy so early snatched away from his books, and gave him lessons; for we learn from the Conversations that "Nat. Field was his scholar, and that he had read to him the Satires of Horace and some Epigrams of Martial."'s Field quotes Latin in the address to the reader before $A$ Woman is a Weathercock, and in the dedication points out the fact that he ends his epistle without a Latin sentence, as if priding himself that he could do so if he wished. ${ }^{6}$ During the hours of study and of rehearsal, he had abundant opportunity to learn the playwright's craft from Jonson himself. The admiration Field felt for his teacher is directly expressed in the verses he wrote in 1611 to his "worthy and beloved friend, Master Ben Jonson, on his Catiline."

But two of Field's comedies survive, A Woman is a

2 Jonson, Worls, II, 199; Bartholomew Fair, V, 3.

3 Schelling, Elizabethan Drama, I, 472-473.

4 Knight, Article in D. N. B. XVIII, 1889.

sonson, Works, III, 477.

- Nero and Other Plays, Mermaid Series, 338-339. 
Weathercock, and Amends for Ladies. We know that he did considerable work of revision and collaboration, but that need not concern us here. The above comedies do credit to the instruction that Field had received, show practical knowledge of the requirements of the stage and intelligent grasp of the fundamental ideas of Jonsonian comedy. The satirical tone adopted reveals at once the source whence Field obtained his attitude in viewing life. His first play, A Woman is a Weathercock, is a satire on the inconstancy of women, and is dedicated "to any woman that hath been no weathercock." In this play the indiscriminate creation of knights by James $I$ is ridiculed:

"Count Frederick. Young Master Abraham! Cry ye mercy, sir.

Abraham Ninny. Your lordship's poor friend and Sir Abraham Ninny.

The dub-a-dub of honor, piping hot,

Doth lie upon my worship's shoulder-blade.

Sir Innocent Ninny. Indeed, my lord, with much cost and labor we have got him knighted; and being under favor, my lord, let me tell ye he'll prove a sore knight, as e'er run at ring. $\mathrm{He}$ is the one and only Ninny of our house." 7

Again, the prevailing injustice in matters of law is bitterly satirized :

\section{"it will be thought}

Your greatness and our money carries it:

For some say some men on the back of law

May ride and rule it like a patient ass,

And with a golden bridle in the mouth

Direct it unto anything they please.

Others report it is a spider's web, Made to entangle the poor helpless flies,

$\tau$ Nero and Other Plays, 352; A Woman is a Weathercock, I, 2. 
Whilst the great spiders that did make it first, And rule it, sit i' th' midst secure and laugh." 8

"He has the advantage of you, being a lord; For should you kill him, you are sure to die, And by some lawyer with a golden tongue, That cries for right (ten angels on his side), Your daring meet him called presumption : But kill he you, he and his noble friends Have such a golden snaffle for the jaws Of man-devouring Pythagorean law, They'll reign her stubborn chops even to her tail: And (though she have iron teeth to meaner men), So master her, that, who displeased her most, She shall lie under like a tired jade." 。

Both $A$ Woman is a Weathercock and Amends for Ladies present vivid and realistic pictures of contemporary life. The scene of the former is laid in the neighborhood of I sondon and of the latter within the city. Both are full of local allusions to such places as the theater at Newington Butts, the Fortune theater in Cripplegate, the cooks' shops of Pie corner in Smithfield, the ducking-ponds at Islington, Moorfields--a noted resort of outcasts, Turnmill Street-a haunt of thieves, or Bear Tavern below London Bridge. Thus Field produces the effect of actuality that Jonson obtains by similar means in The Alchemist or Bartholomew Fair. Effective and realistic, if coarse, presentation of every-day London life we get in such a scene as that inside a tavern, in Amends for Ladies, where Lord Feesimple is introduced among a group of "roaring boys," and by way of drinking a large number of healths is temporarily inspired with the courage of a roarer. ${ }^{10}$

8 Nero and Other Plays, 369; A Woman is a Weathercock, II, 1.

- Nero and Other Plays, 472; Amends for Ladics, IV, 3.

10 Ibid., 456-460; Amends for Ladies, III, 4. 
A number of the characters are conceived and executed on the basis of humors, and given names to indicate the ruling quality. In A Woman is a Weathercock we have Pendant, a sycophant who lives "upon commending" Count Frederick, and whom men call his lord's "commendations"; Sir John Worldly, whose one great desire is for money and who assures us "Worldly's my name, worldly must be my deeds"'; Pouts, the irascible and vindictive captain; and above all, the Ninnies, Sir Innocent Ninny, Lady Ninny and Sir Abraham Ninny. Count Frederick asks: "What countrymen were your ancestors, Sir Abraham?" and that brainless youth replies: "Countrymen! they were no countrymen: I scorn it. They were gentlemen all : my father is a Ninny and my mother was a Hammer." 11 Like Jonson's Matthew, Sir Abraham prides himself on his verses of passionate love, but to unprejudiced critics he is "like a hard-bound poet whose brains had a frost in 'em." Amends for Ladies gives us Welltried, the trusty friend; Bold, of unlimited daring; Lord Proudly, Sir John Loveall, Subtle, Ingen, Ladies Honor, Perfect, and Bright, all sufficiently described by their names; the group of roarers, such as Tearchaps and Spillblood; and the chief humorous character, Lord Feesimple, whose humor is that he grows faint at sight of a naked sword, and who longs, like Jonson's Kastrill, to be taught to quarrel and become a roarer.

Again, in the ready invention and admirable execution of his plots, Field proves that he possessed a practical knowledge of the stage and that he made good use of Jonson's precept and example in the way of careful construction. At the close of $A$ Woman is a Weathercock he takes pains to inform us that the action of the play is included within twelve hours:

"Ne'er was so much (what cannot heavenly powers?) Done and undone and done in twelve short hours." 11 Tero and Other Plays, 353; A Woman is a Weathercock, I, 2. 
He was a skillful playwright, and while the intrigue of the two comedies is intricate and complicated, it is effectively conducted and untangled. The tricks in $A$ Woman is a Weathercock by which Sir Abraham Ninny is gulled into marrying Mistress Wagtail (the waiting-woman), Captain Pouts is punished by Master Strange for slandering his wife, and Bellafront is kept by Nevill from a valid marriage with Count Frederick and so saved for his friend, are clever and interesting. That a masque is used as an organic part of the plot of $A$ Woman is a Weathercock is probably another evidence of Jonson's influence. Though both comedies were written about the same time and there seems no manifest reason for the difference, it is of interest to note that the Amends for Ladies has four or five times as many of the words we found constantly reappearing in Jonson's comedy as occur in the earlier play.

This study of Field's two extant comedies shows unmistakable traces of Jonson's influence in satirical attitude, realistic pictures of London life, construction of plots, and humorous characters.

Among the "Sons of Ben," Richard Brome must be given precedence as having had the best opportunity to gain accurate knowledge of Jonson's methods and spirit in writing comedy, and as having produced the largest number of plays possessing the fundamental characteristics of the comedy of humors. The first reference to Brome that we find is in the induction to Bartholomew Fair where the stagekeeper says: "I am looking lest the poet hear me, or his man, Master Brome, behind the arras" ";2 so that at least from 1614, when this play was written, he was servant to Ben Jonson. As far as we know, he so remained until the master's death in 1637. When The Northern Lass was published in 1632, Jonson stood as sponsor for it and wrote commendatory verses "to my old faithful servant, and (by his continued virtue) my loving friend, 12 Jonson, Works, II, 143. 
Mr. Richard Brome." Not only as a servant and friend does Jonson praise him, but also as a follower of the comic laws he himself had taught:

"I had you for a servant once, Dick Brome, And you performed a servant's faithful parts ;

Now you are got into a nearer room Of fellowship, professing my old arts. And you do them well, with good applause, Which you have justly gained from the stage, By observation of those comic laws Which I, your master, first did teach the age. You learned it well, and for it served your time, A prenticeship, which few do nowadays." 13

That Brome had the advantage of daily association with Jonson during years is a fact of great significance and he must have learned much and gained much. It was also in collaboration with Jonson's son that he began his dramatic career with a non-extant play, $A$ Fault in Friendship, licensed in 1623 as "by Brome and young Jonson."

Brome himself refers with pride to Jonson as his teacher and master. In verses prefixed to the Beaumont and Fletcher folio of 1647 , he writes of him

"That was the master of his art and me, Most knowing Jonson." 14

The prologue to The City Wit tells us the play

$$
\text { "was written, when }
$$

It bore just judgment, and the seal of Ben." ${ }_{15}$

In the epilogue to The Court Beggar, the author seems to 13 Brome, Works, III, p. IX.

14 Beaumont and Fletcher, Works, I, 92.

15 Brome, Works, I, 276. 
refer to Jonson in writing of him "by whose care and directions this stage is governed, who has for many years . . . directed poets to write and players to speak till he trained up these youths here to what they are now." 16 Many a time Brome must have gone with Jonson to the Devil Tavern and heard given the order embodied in The English Moor to "draw a quart of the best Canary into the Apollo." 17

According to the testimony of the commendatory verses prefixed to his plays, Brome seems to have been on good terms with many other dramatists and poets of the time, and these generally show that they considered him frankly as an imitator and follower of Jonson. Thomas Dekker, John Ford, James Shirley, John Tatham, Sir Aston Cockayne, John Hall, and Alexander Brome, wrote in warm praise of his work. A number of these connect directly the names of Brome and Jonson. Prefixed to The Antipodes are some lines by C. G. beginning:

"Jonson's alive! the world admiring stands," and ending

"Therefore repair to him, and praise each line Of his Volpone, Sejanus, Catiline. But stay, and let me tell you where he is, He sojourns in his Brome's Antipodes!"18

John Hall writes concerning A Jovial Crew:

"You do not invade, But by great Jonson were made free o' th' trade, So that we must, in this your labor find Some image and fair relique of his mind." ${ }_{19}$

16 Brome, Works, I, 272.

17 Ibid., II, 41, The English Moor, III, 2.

18 Ibid., III, 229.

10 Ibid., III, 345. 
With regard to the same play, John Tatham hopes the audience

"May be conformable to Ben's influence; And finding here nature and art agree May swear, thou liv'st in him and he in thee." 20

The ode by Thomas Randolph in answer to Jonson's Ode to Himself after the failure of The New Inn in 1629, makes uncomplimentary reference to "what Brome swept from thee." ${ }_{21}$ On the title-page of The Weeding of Covent Garden as published in 1658, the author is described as "an ingenious servant and imitator of his master, that famously renowned poet, Ben Jonson." We have, then, full and complete evidence that Brome was regarded by his master, by his contemporaries, and by himself as a follower of Ben Jonson in English comedy, and the plays themselves confirm the judgment.

Fifteen independently written plays are extant. Of these, three are distinctively romantic tragi-comedies: The Lovesick Court, The Queen's Exchange, The Queen and the Concubine; two more have large romantic elements: The Novella and The English Moor; and the remaining ten are pure comedies of manners and of humors based on the every-day life of London. From the last group chiefly do we get the material for a study of Jonson's influence on Brome. In the romances Ward finds traces of the influence of Shakespeare, Fletcher and Massinger. ${ }^{22}$ Koeppel discovers parallels between A Mad Couple WellMatched, The City Wit, The Court Beggar, The Antipodes, The English Moor, The Lovesick Court, The Queen's Exchange, The Queen and the Concubine, and various Shakespearian plays. ${ }^{23}$ We must remember that Jonson himself 20 Brome, Works, III, 348. 21 Jonson, Works, II, 387.

22 Ward, III, 129-131.

23 Koeppel, Studien uber Shakespeare's Wirkung, 42-47. 
yielded in part to the allurement of the romantic method in his early The Case is Altered and his late The New Inn.

Let us see, first of all, what is the evidence of the prologues and epilogues regarding the extent to which Brome had absorbed Jonson's theories of comedy. In the epilogue to The English Moor he expresses his wish that

"You judge but by the ancient comic laws.

Not by their course who in this latter age

Have sown such pleasing errors on the stage,

Which he no more will choose to imitate." 24

Again, in the prologue to The Novella:

"He'll bide his trial, and submits his cause To you the jury, so you'll judge by laws." 25

He proceeds in this same prologue to ask judgment only from the judicious and to address his audience quite in Jonson's tone of independence:

"If pride or ignorance should rule, he fears An unfair trial, 'cause not tried by's peers. Faith, be yourselves a while, and pass your vote On what you understand, and do not dote On things 'bove nature or intelligence; All we pretend to is but mirth and sense."

The prologue to The Sparagus Garden again repeats that the author never did

$$
\text { "strive }
$$

By arrogance or ambition to achieve

More praise unto himself, or more applause

Unto his scenes, than such, as know the laws

Of comedy do give; he only those

Now prays may scan his verse and weigh his prose." 26

24 Brome, Works, II, 86.

25 Ibid., I, 104.

26 Ibid., III, 115. 
Brome would, like Jonson, appeal to the intellect rather than the heart, and he intends that

"No handsome love-toy shall your time beguile, Forcing your pity to a sigh or smile." ${ }^{27}$

Nevertheless, a love-story does run through every one of his comedies, and while the love-motive is not always the predominant one, yet it is used much more freely and fully than by Jonson. The master's preference for "deeds and language such as men do use" has affected the disciple and he condemns those

"That count all slight that's under us or nigh;

And only those for worthy subjects deem,

Fetched or reached at (at least) from far or high;

When low and home-bred subjects have their use,

As well as those fetched from on high or far." 28

The prologues are marked by a decided self-consciousness but it is not masterful and confident as was that of Jonson. A strange mixture of self-praise and self-depreciation appears in such prologues as those to The Northern Lass, The Demoiselle or The Queen's Exchange. In the last we find this:

"The writer of this play who ever uses To usher with his modesty the muses Unto the stage, he that scarce ever durst Of poets rank himself above the worst, Though most that he has wit has passed the rest, And found good approbation of the best; $\mathrm{He}$, as he never knew to bow, he says, As little fears the fortune of his plays." 29

27 Brome, Works, I, 184.

28 Ibid., III, 230.

29 Ibid., III, 456. 
From the prologues we learn that Brome aimed to regard the laws of Roman comedy, to value the criticism of the judicious only, make chief appeal to the intellect and present chiefly "low and homebred subjects"; and that, furthermore, as a playwright he was a thoroughly selfconscious workman. We should note, on the other hand, the absence of the assertion of didacticism, the reminder that we are to have profit mixed with our delight, constantly found in Jonson's prologues.

While Brome was not primarily concerned with scourging vices and follies, yet again and again within the plays he asserted the purpose of purging or, curing individuals, groups of persons, or places. However, the moral and ethical attitude taken by him seems often assumed, put on from the outside, and not deeply ingrained in the whole philosophy of life as with Jonson. He usually accepted conventional moral standards, but never attained to a really vital grasp of the spirit of morality. Brome sometimes, as in A Mad Couple Well Matched, lost a true sense of moral values; Jonson never was guilty of such offense. We are definitely told that the aim is to "purge" and "cure" certain personages of the comedies, as, Sir Swithin Whimbly, the Crying Knight, and Camelion, the uxorious citizen, in The New Academy; Pyannet, the scold, in The City Wit; Joyless, the jealous old husband of a young wife, and Peregrine, a monomaniac on the subject of traveling, in The Antipodes; or in The Court Beggar, Citwit, whose habit is to abuse everybody and never stand by anything he has said. The object in The Sparagus Garden, we are told, is to "run jealousy out of breath" and to "purge the place of all foul purposes." Here are of interest some lines written by C. G. on this play:

"It is no common play.

Within thy plot of ground, no weed doth spring 
To hurt the growth of any underling;

Nor is thy labyrinth confus'd, but we

In that disorder may perfection see.

Thy herbs are physical and do more good

In purging humors than some's letting blood." 30

The plays are full of satirical pictures of conditions and classes of every day London life. We find the realism not only of definite localization but of direct portrayal of life seen "from below stairs," ${ }^{31}$ sometimes gross and repulsive, but showing keenness and variety of satirical observation. Brome knew and knew well "the coarse and gross and seamy side of life," and no finer sensibilities kept him from picturing it often with "prosaic ruthlessness." 32 Usually, he did have an honest purpose to further the cause of morality. The Weeding of Covent Garden is a direct attempt to promote a definite social reform in a certain neighborhood. In the second prologue, written after the play had accomplished the desired practical results, the audience is urged to

\section{"take the same survey,}

Into your fancy, as our poet took

Of Covent Garden, when he wrote his book

Some ten years since, when it was grown with weeds,

Nor set, as now it is, with noble seeds

Which make the garden glorious ;"

and to remember how

\section{"'happily his pen}

Foretold its fair improvement, and that men Of worth and honor should renown the place." ${ }_{33}$

30 Brome, Works, III, 113.

31 Schelling, II, 336.

32 Symonds, The Academy, March, 1874.

33 Brome, Works, II, 178. 
Projects or speculations in monopolies, one of the greatest abuses of the time, and most effectively ridiculed in The Devil is an Ass, Brome satirizes again and again, in The Demoiselle, The Weeding of Covent Garden, The Sparagus Garden, The Antipodes, and The Queen's Exchange, while The Court Beggar finds here its chief theme. In the last play, most of the characters in jest or earnest put forth some project. Here are two of interest:

"My project is that no plays may be admitted to the stage but of their making who profess or endeavor to live by the quality; that no courtiers, divines, students at law, lawyers' clerks, tradesmen or prentices, be allowed to write 'em, nor the works of any poet whatsoever to be received to the stage, though freely given unto the actors; nay, though any such poet should give a sum of money with his play, as with an apprentice, unless the author do also become bound that it shall do true and faithful service for a whole term;" 34

"a new project

For building a new theater or play-house Upon the Thames on barges or flat boats, To help the watermen out of the loss They've suffer'd by sedans." 35

A passage on the same subject in The Antipodes is worth quoting for the utter absurdity of the schemes:

"Your projects are all good. I like them well, Especially these two: this for th' increase of wool; And this for the destroying of mice: they're good, And grounded on great reason. As for yours, For putting down the infinite use of jacks, Whereby the education of young children In turning spits is greatly hindered, It may be looked into. And yours against 34 Brome, Works, I, 215; The Court Beggar, II, 1. 35 Ibid., I, 194; The Court Beggar, I, 1. 
The multiplicity of pocket watches,

Whereby much neighborly familiarity

By asking, what d'ye guess it is a clock?

Is lost, when every puny clerk can carry

The time o' the day in's breeches. This and these

Hereafter may be looked into. For present,

This for the increase of wool, that is to say,

By flaying of live horses and new covering them

With sheep-skins, I do like exceedingly.

And this for keeping tame owls in cities

To kill up rats and mice, whereby all cats

May be destroyed, as an especial means

To prevent witcheraft and contagion." 36

The "roarers" with whom we became familiar in the comedies of Jonson and his immediate contemporaries, and whom we met again in Field's plays, are satirized by Brome both as "roarers" or members of the "roaring brotherhood" and as "blades," in The Demoiselle, The Weeding of Covent Garden, and The Northern Lass. Throughout The Weeding of Covent Garden, Brome attacks the Puritans in the character of Gabriel. The following shows clearly direct relation to Jonson's satire in The Alchemist and Bartholomew Fair:

"Gabriel. It is nevertheless a tavern, brother Mihil, and you promised and covenanted with me at the last house of noise and noisomeness, that you would not lead me to any more taverns.

Mihil. Lead you, brother? Men use to be led from taverns sometimes. You saw I did not lead you nor bring you to any that was more a tavern than the last, nor so much neither; for here is no bush, you saw.

Gab. 'Twas that betrayed and entrapped me; but let us yet forsake it.

36 Brome, Works, III, 308; The Antipodes, IV, 9. 
Mih. Pray, let us drink first, brother. By your leave, here's to you.

Gab. One glassful more is the most that I can bear. My head is very full, and laboreth with that I have had already.

Mih. There, sir, I'll undertake one good fellow, that has but just as much religion as will serve an honest man's turn, will bear more wine than ten of these giddybrained Puritans; their heads are so full of whimsies.

Gab. 'Tis mighty heady, mighty heady, and truly I cannot but think that the over-much abuse of these outlandish liquors have bred so many errors in the Romish Church.

Mih. Indeed, brother, there is too much abuse made of such good creatures. Wine in itself is good, you will grant, though the excess be naught; and taverns are not contemptible, so the company be good.

$G a b$. It is most true, we find that holy men have gone to taverns, and made good use of 'em upon their peregrinations.

Mih. And cannot men be content to take now and then a cup, and discourse of good things by the way? As thus, brother, here's a remembrance, if she be living and have not lost her honor, to our cousin Dorcas.

Gab. O that kinswoman of ours! She was the dearest loss that e'er fell from our house.

Mih. Pledge her, good brother.

Gab. I do-

Mih. I hope 'twill maudlinize him.

Gab. But have you never seen that miscreant that wronged her, since he did that same? They say you knew him. Mih. Alas, suppose I had, what could be done? She's lost, we see. What good could she receive by any course against him?

Gab. It had been good to have humbled him, though, into 
the knowledge of his transgression. And of himself, for his soul's good either by course of law, or else in case of necessity, where the law promiseth no release, by your own right hand you might have smote him, smote him with great force, yea, smote him unto the earth, until he had prayed that the evil might be taken from him.

Mih. This is their way of loving enemies, to beat 'em into goodness. Well, brother, I may meet with him again, and then I know what to do." ${ }^{37}$

From his master Brome had imbibed a thorough-going dislike for gentlemen of fashion, and he ridicules them with as strong feeling as Jonson, if not with as telling satire. In The City Wit the question is asked: "Dost thou know what a gallant of fashion is?" and the answer given: "I'll tell thee. It is a thing that but once in three months has money in his purse, a creature made up of promise and protestation, a thing that . . . flatters all he fears, contemns all he needs not, starves all that serve him, and undoes all that trust him." 38 The rules for being a courtier are: "Speak nothing that you mean, perform nothing that you promise, pay nothing that you owe, flatter all above you, scorn all beneath you, deprave all in private, praise all in public, keep no truth in your mouth, no faith in your heart, no health in your bones, no friendship in your mind, no modesty in your eyes, no religion in your conscience, but especially no money in your purse." $\mathbf{3 9}$

Occasionally the citizens get their turn: "A good man i' the city is not ealled after his good deeds but the known weight of his purse" ;40 and Pyannet in The City Wit scoffs at the idea of an honest citizen: "Honest man! who the

37 Brome, Works, II, 61-62; The Weeding of Covent Garden, IV, 1. 38 Ibid., I, 292; The City Wit, I, 2.

39 Ibid., I, 306; The City Wit, II, 3.

40 Ibid., III, 23; The Northern Lass, II, 1. 
devil wished thee to be an honest man? Here's my worshipful husband, Mr. Sneakup, that from a grazier is come to be a justice of peace, and what, as an honest man? He grew to be able to give nine hundred pound with my daughter; and what, by honesty? Mr. Sneakup and I are come up to live i' the city, and here we have lain these three years, and what, for honesty? Honesty! What should the city do with honesty when 'tis enough to undo a whole corporation? Why are your wares gummed; your shops dark; your prizes writ in strange characters; what, for honesty? Honesty! Why is hard wax called merchants' wax, and is said seldom or never to be ripped off but it plucks the skin of a lordship with it? What, for honesty?" 41

In the construction of his plots, as we have seen, Brome purposed to follow the classic rules, and we do find comparative regularity. He was a skilled and trained workman, a clever playwright who had learned his craft from Jonson and knew well the requirements of the stage. He was ingenious and inventive, and some of the plays, as The Northern Lass, A Jovial Crew, The Antipodes, and The City Wit, have original situations that remain distinctively in mind. As in Jonson's plays, we have complicated intrigue, trickery and roguery of all kinds, usually skillfully managed. Sometimes Brome fell into the error, from which Jonson was by no means always free, of crowding the stage with figures and entangling the action with schemes so many and varied that confusion and bewilderment result. Throughout, the method of Jonson is clearly discernible in the construction of the plays.

There are situations that directly or indirectly recall Jonson's comedies. The Weeding of Covent Garden is modeled on Bartholomew Fair, and the debt frankly acknowledged. Cockbrain, like Justice Overdo, zealously 41 Brome, Works, I, 284-285; The City Wit, I, 1. 
disguises himself and goes among the roisterers and lawbreakers of Covent Garden, only to meet with experiences similar to those of his worthy predecessor when he went to Bartholomew Fair. As Cockbrain girds up his courage for investigation and reform, he says: "And so, as my reverend ancestor, Justice Overdo, was wont to say, 'In heaven's name and the King's, and for the good of the commonwealth, I will go about it." "42 Gabriel, with his cant phrases and assumed piety, goes to Covent Garden as Zealof-the-land Busy to Bartholomew Fair; and Clotpoll, the foolish gull with plenty of money to spend, is closely related to Bartholomew Cokes in folly and resulting mishaps.

In The Court Beggar, the group of projectors working upon Sir Andrew Mendicant and persuading him they can make him a rich lord, recall the gulling of Fitzdotterel in The Devil is an Ass. Swinburne thinks that the influence of Volpone is evident in The Novella. ${ }^{43}$ There may be a slight reminiscence of Volpone and Mosca in the manner in which Victoria, the Novella, and her servant Paulo set up an establishment and seek to draw men of all kinds to them, but the purpose, methods and characters are entirely different. The plot of The City Wit is decidedly Jonsonian in its processes of gulling and tricking a large group of persons by a small group. Crazy, a young citizen who has lost his money and whose friends have turned against him, Jeremy his boy servant, and Crack, another boy, make covenant together, "like Subtle, Doll and Face," ${ }_{44}$ to cozen the other characters, and they succeed admirably. The influence of The Alchemist is manifest in the situations that follow. Further, the boy Jeremy is dressed as a woman and marries, as the boy in Epicone. The School of Compliment in The New Academy takes us back again

\footnotetext{
42 Brome, Works, II, 2; The Weeding of Covent Garden, I, 1. 43 Fortnightly Review, LVII, 1892.

44 Brome, Works, I, 318; The City Wit, III, 1.
} 
to The Devil is an Ass and Epicœne with their expositions of fashion and compliment. The suggestion for The Antipodes, Ward thinks, may have been taken from Jonson's masque The World in the Moon. ${ }^{45}$

Brome in The Sparagus tells us what he thinks of humors: "For as in every instrument are all tunes to him that has the skill to find out the stops, so in every man are all humors to him that can find their faucets, and draw 'em out to his purpose." 46 In choice and execution of comic types Brome shows constantly strong evidence of Jonson's influence. Often we do get tricks and humors rather than persons, but that is true also of Jonson, and some of Brome's humorous characters are original, interesting and distinctive. The finer powers of Jonson in bringing out the subtle individuality of the representative of a type Brome does not possess. He lacks the true artistic sense that hides bare fundamental conception, and he is often too conscientiously concerned that his idea shall be fully grasped. This is evident in the way he sometimes points out the applicability of a name, as that of Touchwood in The Sparagus Garden: "He has not his name for nothing, old Touchwood! He is all fire if he be incensed; but so soft and gentle that you may wind him about your finger or carry him in your bosom if you handle him rightly; but still, be wary, for the least spark kindles him." 47 Brome follows closely Jonson's custom of naming characters so as to indicate ruling quality or humor. Frequently he identifies his persons by means of eatch phrases or sayings, "tags," and sometimes falls into mere caricature. Striker in The Sparagus Garden constantly reiterates, "there I am wi' ye," and Hearty in A Jovial Crew, "there's a whim now"; Geron of The Love-Sick Court is

45 Ward, III, 130.

46 Brome, Works, III, 160; The Sparagus Garden, III, 4.

47 Ibid., III, 117-118; The Sparagus Garden, I, 1. 
forever comparing everything to "as whilom said" or "as whilom did" someone sometime; Saleware in A Mad Couple Well Matched quotes on every possible occasion, "Sapientia mea mihi, stultitia tua tibi."

The personages that stand out most clearly in the comedies are with few exceptions characters created according to the theory of humors. Justice Bumpsey of The Demoiselle, one of Brome's most original creations, by his humor of spending recklessly an equal amount of money in a like manner, cures his son-in-law of useless extravagance. The humor of his "fashion-sick" wife is to "learn and practice carriage." Pyannet who has "the tongue-ague," Sarpego, the wearisome pedant, and Linsy-Wolsey, the miserly citizen, in The City Wit, are Jonsonian types. So also are Sir Andrew Mendicant, of The Court Beggar, who sells his. country estate to purchase wit at court and is duped into believing he may obtain a lordship by means of wild projects; Lady Strangelove, "the humorous widow that loves to be courted;" Sir Raphael Winterplum, "who has licked up a living with his tongue, makes all great tables his own, and eats for his talk;" and Citwit, whose humor is to answer all questions asked, whether addressed to him or not, abuse everybody spoken of, and, when called to account, excuse himself from a quarrel by declaring he spoke only "comparatively." In The Weeding of Covent Garden, Cockbrain, the reforming justice, and Gabriel, the supposed saintly Puritan, as we have seen above, bear direct likeness to Justice Overdo and Zeal-of-the-land Busy in Bartholomew Fair; Clotpoll is another country gull who has come to town with money and is anxious to learn to roar and be a gentleman; and Crosswill objects to everything proposed and crosses his children in all they ask, so that they must get what they want by seeming to seek the very opposite.

Mrs. Crostill, the humorous widow of A Mad Couple 
Well Matched, is also moved by a spirit of contradiction, and is won by the suitor that slights her most. Saleware of this same play is foolishly proud of his courtly wife and refuses to be made jealous, considering every plain piece of evidence of her unfaithfulness but a plot to make him jealous. Rafe Camelion in The New Academy is another doting husband, as blind as Deliro in Every Man out of His Humor and as effectively disillusioned. Sir Swithin Whimbly, "the crying knight," always weeps at the mention of his dead wife, is "inspired with the infection of poetry" whenever he thinks of her, and is cured by one of the other characters who sets out to "turn the tide of's tears." Matchill marries his maid to spite his daughter and kindred, thinking to get "a rare piece of obedience," but finds himself sadly mistaken. Justice Clark of A Jovial Crew, in trying cases, does all the talking and testifying himself; for "if we both speak together, how shall we hear one another?" He tells a witness: "I can inform myself, sir, by your looks. I have taken a hundred examinations i' my days, of felons and other offenders, out of their very countenances, and wrote 'em down verbatim to what they would have said. I am sure it has served to hang some of 'em and whip the rest." 48

There are several characters of humors in The Northern Lass: Widgine, a silly verse-maker who continually quotes his sister, takes pride in his tutor's wit, and is a weaker combination of Stephen and Matthew in Every Man in His Humor; Captain Anville, a braggart and faint shadow of Bobadil; Sir Solomon Nonsense, a Cornish countryman and "a parrot or a popinjay"; and Howdee, who aspires to the position of a gentleman usher and diligently cons "the ushers' grammar." Buzzard in The English Moor, as Ward points out, ${ }^{49}$ is evidently a relation to Jonson's

48 Brome, Works, III, 435; A Jovial Crew, IV, 2.

49 Ward, III, $129^{2}$. 
Sir Amorous La-Foole. "The Buzzards," he tells us, "are all gentlemen. We came in with the Conqueror. Our name (as the French has it) is Beau-Desert, which signifies -Friends, what does it signify?" 50 Geron, the pedant of The Lovesick Court, has a humor of whiloming so persistently that even his doting old mother exclaims impatiently, "Forbear your whiloms and your old said saws," while the lady whom he courts, when told that he loves her, declares :

"That's more than I e'er knew or read by all $\mathrm{He}$ speaks or writes of me. $\mathrm{He}$ clothes his words In furs and hoods, so that I cannot find The naked meaning of his business." 51

His old mother, Garrula, bears out her name and for very talking cannot tell the news she comes to bring.

The comedies contain many other characters of humors, but these suffice to show the types presented. A certain rigidity and artificiality we do find, but some of the personages are original and interesting and show that Brome had a broad sense of humor and a real knowledge of the foibles and follies of human nature. The influence of Jonson is constantly evident in conception and in method of portrayal. However, Brome produced, on the whole, few direct imitations of Jonson's characters. It was the general theory that he learned thoroughly and applied faithfully.

Brome appears to have acquired a certain amount of learning and makes some show of classical knowledge. In several plays he attempts to give the impression of such a background, but in general he was neither supported nor weighed down by Jonsonian learning. We find an abundance of Latin quotations in The City Wit and The Queen

so Brome, Works, II, 43; The English Moor, III, 2.

51 Ibid.; II, 123; The Lovesick Court, III, 1. 
and the Concubine, and in some of the plays, as The City Wit, The Lovesick Court and The Court Beggar, allusions to classical writers are frequent. It is worth noting, too, that these plays are all among Brome's earliest productions. $\mathrm{He}$ occasionally makes a display of out of the way learning, as in the enumeration of dances in The New Academy, the military terms of The Weeding of Covent Garden, or the beggar's peculiar dialect in A Jovial Crew.

The vocabulary used in the plays shows, on the whole, much less likeness to Jonson's than might have been expected, not nearly so much as that of some of the playwrights studied in the preceding chapter. The largest number of words we find in The City Wit, The Demoiselle, The Court Beggar, The Weeding of Covent Garden and The Sparagus Garden. These plays present Brome's most realistic and direct pictures of contemporary life, and so use the words of common street and tavern talk most frequently. Verse and prose are used in varying proportions. Brome was not a poet, and his rough, halting verse, though aiming at regularity, can hardly be said to show Jonson's influence.

A study of Brome's plays bears out fully the testimony of Jonson and of contemporaries, as well as the claim of Brome himself, that he was a "Son of Ben." In conscious theory and in practical application he followed after his master, however afar off when judged as to intellectual mastery and literary genius. His realistic pictures of contemporary life, moral satire, plots of complicated intrigue, and characters of humors, testify clearly who was his teacher in the art of writing comedy. 


\section{CHAPTER IV}

OTHER "SONS OF BEN" IN ENGLISH COMEDY BEFORE THE CLOSING OF THE THEATERS IN 1642.

During the years between 1620 and 1642 , a considerable number of writers in one or more plays tried their hand at the Jonsonian comedy of humors. Many of these were gentlemen, and did not, like the dramatists whom we have previously studied, find a profession and a livelihood in connection with the stage, but wrote an occasional play as a diversion from their work as preacher, teacher, soldier or statesman. With some of them, we discover in commendatory verses and direct references of one kind or another, evidences of personal relation to Jonson; but with others, only from a study of their plays do we know that they admired and sought to imitate his comedy. They did not, like the earlier and greater playwrights, work side by side with him as comrades and rivals, but were, sometimes near and sometimes far off, followers of an acknowledged master. Some show his general influence in humorous personages, satiric tone and plots of gullery; others are direct and close imitators of particular passages and plots. Many of this group, though just what ones we do not always know, must have shared in the happy feasts of wit and laughter at the Devil Tavern. To curious students, a membership list of those admitted by Ben to his sacred circle, would be of decided interest.

Thomas May, a Cambridge graduate, a lawyer of Gray's Inn, and in his earlier years a member of court circles, was allied to Jonson in his love of classical learning and his production of English tragedies on historical themes, as 
well as in his one comedy of manners and humors. $\mathrm{He}$ has been better known as an historian of the Long Parliament than as a dramatist. Langbaine tells us that in his university days "he was a very close student and what stock of learning he then treasured up is apparent from his works." 1 Virgil's Georgics, some of Martial's Epigrams and Lucan's Pharsalia were translated by him, and the last of these, to quote Langbaine again, "is extremely commended by our famous Jonson." 2 About this work Jonson wrote "To my chosen friend, the learned translator of Lucan, Thomas May, Esquire," a highly complimentary poem, and signed it, "your true friend in judgment and choice, Ben Jonson." 3 To the Jonsonus Virbius May contributed a poem in praise of "Great Jonson, King of English poetry," his "judgment, art and wit." " Although the classical tragedies, Cleopatra, Julia Agrippina, Antigone, and Julius Casar, are largely affected by the contemporary spirit of romance and the work of Fletcher, yet they show a frank following of Jonson in choice and treatment of material. ${ }^{\circ}$

It is with May's one comedy of manners, The Old Couple, that we are especially concerned here. This play was not printed until 1658, but Fleay considers it to have been written before The Heir, a tragi-comedy on the accepted Fletcherian model definitely stated to have been acted in 1620 , and so dates it 1619 or $1620 .^{\circ}$ The general conduct of the plot, which is originally conceived and planned, tends toward the romantic method rather than the Jonsonian in such situations as that of Scudmore, supposed to be slain but disguised as Lady Covet's chaplain while

1 Langbaine, 360.

2 Ibid., 364.

3 Jonson, Works, III, 294-295.

4 Ibid., III, 504.

s Schelling, II, 45, 268.

- Fleay, II, 83. 
his betrothed lady wanders about in a wood singing songs of bitter lament, or of Eugeny in close hiding in the wood from pursuit for the murder he thinks he has committed. However, in the schemes by which the miserly old people, Sir Argent Scrape, Lady Covet and Earthworm are cured of their avarice, and the simple gull Dotterel is fooled into marrying Lady Whimsey, as well as in the regard for the unities of time and place, we find traces of Jonson's influence.

The moral intent of The Old Couple is unmistakable. That it was "chiefly designed an antidote against covetousness," Langbaine had no doubt. ${ }^{7}$ Not only in the general theme do we discover the ethical purpose but in expository moral utterances on avarice and charity, and in plain statements of intention to "purge" and "cure" the covetous-minded personages. A number of the characters have descriptive names, are conceived along simple lines as possessing a ruling quality, and are somewhat influenced by the allegorical point of view, yet they are far from being mere abstractions. Dotterel, the gull who is with good reason not afraid of his brain being hurt by wine, is most fully Jonsonian in conception and portrayal. We have before noted Jonson's fondness for references to and analogies with the foolish dotterel, particularly as shown in the name and character of Fitzdotterel of The Devil is an Ass. The Dotterel of The Old Couple Lady Whimsey succeeds in marrying, and thus also she gets control of his wealth :

\section{"Euphues. Our Dotterel, then, is caught?}

Barnet. He is, and just

As Dotterels used to be: the lady first

Advanc'd toward him, stretch'd forth her wing, and he

i Langbaine, 364. 
Met her with all expressions; and he's caught

As fast in her lime-twigs as he can be,

Until the church confirm it.

Euph. There will be

Another brave estate for her to spend.

Bar. Others will be the better for't; and if

None but a Dotterel suffer for't, what loss

Of his can countervail the least good fortune

That may from thence blow to another man?" 8

The construction, didactic purpose and personages of The Old Couple indicate a general acquaintance with the methods of Jonson, and not a direct imitation of individual plays nor even a close following of theories.

Robert Davenport can hardly be called a "Son of Ben," yet he deserves brief notice here as having felt, though only to a slight extent and at long range, the influence of Jonson's theory of humors. His two comedies, The City Night-Cap and A New Trick to Cheat the Devil, illustrate well the way in which the idea of humors had become a common dramatic possession and crept now and again, perhaps often with little conscious thought on the part of the writer, into plays which otherwise exhibit no traces of Jonson's methods. Lodovick of The City Night-Cap, licensed in 1624, persists in foolishly trusting a faithless wife, asserting "my humor's my humor" and forever repeating "crede quo habes et habes." In A New Trick to Cheat the Devil, printed in 1639, Treatwell, Master and Mistress Changeable, and Slightall, are described by their names and in a vague and general way have their humors. One of the persons of this play pleads for quiet and declares

8 Dodsley's Old English Plays, ed. by Hazlitt, XII, 41; The Old Couple, III, 1. 
"I'm like the man that could endure no noise In th' Silent Woman, answer all in signs." 9

Thomas Randolph spent a great part of his short life of twenty-nine years at the Universities of Cambridge and Oxford, was a gentleman, a scholar, a poet, and the chief university dramatist of the time. By reason of his Amyntas, one of the two or three best Elizabethan pastoral dramas, his Hey for Honesty, a readaptation of Aristophanes' Plutus, the farcical dialogue of Aristippus and monologue of The Conceited Pedlar, two comedies, The Jealous Lovers, and The Muses' Looking-glass, and his various short poems, Randolph holds a high place among the "Sons of Ben." Complimentary verses testify to his friendship with James Shirley and Sir Aston Cockayne, and we have abundant evidence of his admiration and affection for Jonson. A study of such writers as May, Randolph and Cartwright, whose work bears a decidedly academic stamp and likewise has a clear relation to the comedy of humors, makes us wish that we knew just what was Jonson's contact with the universities, and whether perhaps he came in touch directly on academic ground with the writers of college drama.

While an undergraduate, Randolph seems to have made the acquaintance of Jonson, and the following anecdote, interesting, whether or not authentic, has been handed down:

"Randolph, who was then a student in Cambridge, having stayed in London so long that he might truly be said to have had a parley with his empty purse, was resolved to see Ben Jonson with his associates, who, as he heard, at a set time kept a club together at the Devil Tavern, near Temple Bar. Accordingly he went thither at the specified

- Bullen's Old Plays, New Series, III, Works of Davenport, 292; A New Trick to Cheat the Devil, V, 3. 
time; but, being unknown to them, and wanting money, which, to a spirit like Tom's, was the most daunting thing in the world, he peeped into the room where they were, and was espied by Ben Jonson, who, seeing him in a scholastic threadbare habit, cried out, 'John Bo-peep, come in!' which accordingly he did. They immediately began to rhyme upon the meanness of his clothes, asking him if he could not make a verse, and withal to call for his pot of sack. There being but four of them he immediately replied-

\section{“' 'I John Bo-peep,}

To you four sheep,

With each one his good fleece;

If that you are willing,

To give me five shilling,

'Tis fifteen pence a piece.'

'Why,' exclaimed Ben Jonson, 'I believe this is my son Randolph'; which being made known to them, he was kindly entertained in their company, and Ben Jonson ever after called him his son." 10

By several contemporary writers Randolph's name is closely linked with that of Jonson. Among some verses before Harding's Sicily and Naples or the Fatal Union, 1640 , are these:

"Thus, friend, the bays still flourish. Jonson dead, Randolph deceas'd, they fall to crown thy head."

In The Poet's Condition, 1662, by Rowland Watkyns, the two poets are named together:

"What lands had Randolph, or great Ben?"

10 Randolph, Works, Introduction, XI. Hazlitt's New London Jest-Book, 1871, p. 338.

11 Ibid., I, p. XIII. 
The writer of the preface to the reader before Hey for Honesty tells us that "the adopted son of Ben Jonson, being the translator hereof, followed his father's steps; they both of them loved sack and harmless mirth." 12

Richard West writes of Randolph:

"Read's flow'ry pastorals, and you will swear He was not Jonson's only, but Pan's heir." ${ }^{13}$

In some dedicatory verses G. W. calls him again "true son and heir" of "immortal Ben." ${ }^{14}$

Three poems Randolph himself wrote to Jonson. The first is "A gratulatory to Master Ben Jonson for his adopting of him to be his son." He glories in the honor bestowed on him:

"thy adoption quits me of all fear, And makes me challenge a child's portion there.

. . Ovid, Virgil and the Latin lyre

That is so like thee, Horace, the whole quire

Of poets are, by thy adoption, all

My uncles

Being son of his adoption boast I must,

And to say truth, that which is best in me May call you father; 'twas begot by thee.

Have I a spark of that celestial flame

Within me? I confess I stole the same

Prometheus-like, from thee." ${ }^{15}$

Another poem is " An answer to Master Ben Jonson's Ode,

12 Randolph, Works, II, 376.

13 Ibid., II, 517.

14 Ibid., II, 507.

15 Ibid., II, 537-538. 
to persuade him not to leave the stage" after the failure of The New Inn, 1629, for

"I know thy worth, and that thy lofty strains

Write not to clothes, but brains.

But thy great spleen doth rise,

Cause moles will have no eyes;

This only in my Ben I faulty find,

He's angry, they'll not see him that are blind." ${ }_{16}$

In "An Eclogue to Master Jonson" Tityrus is Jonson and Damon, Randolph. Damon has broken his reed and does not care to mend it. Tityrus urges him to continue to serve the muses, for

\section{"I meant to thee}

Of all the sons I have, by legacy

To have bequeath'd my pipe. Thee, thee of all

I meant it should her second master call." ${ }^{17}$

Randolph's dramatic work was done between the years 1629 and 1633, and includes a pastoral, a dialogue, a monologue and three comedies. The testimony of contemporaries and the full recognition of debt from Randolph himself would make us expect to find in his work many evidences of Jonson's influence. Randolph, however, was a close student and genuine lover of the classics, and drew first hand from Aristophanes, Plautus and Terence, as Jonson had done, ideas about plot, satire and character in comedy. Whether Jonson had anything to do with the direction Randolph's study and interest took, we do not know. Edward Fraunces wrote of The Jealous Lovers:

10 Randolph, Works, II, 582-583.

11 Ibid., II, 606. 
"if by chance, through injury of time,

Plautus and Terence and that fragrant thyme

Of Attic wit should perish, we might see

All those reviv'd in this one comedy." 18

In The Muses' Looking-glass the moral value of comedy is very fully set forth:

"On the stage

We set an usurer to tell this age,

How ugly looks his soul : a prodigal

Is taught by us, how far from liberal

His folly bears him. Boldly, I dare say,

There has been more by us in some one play

Laugh'd into wit and virtue, than hath been

By twenty tedious lectures drawn from sin

And foppish humors: hence the cause doth rise,

Men are not won by th' ears so well as eyes." 10

Again, the soul sees her face

In comedy, and has no other glass." 20

Comedy works "with shame-

A thing more powerful in a generous breast.

Who sees an eating parasite abus'd;

A covetous bawd laugh'd at; an ignorant gull

Cheated; a glorious soldier knock'd and baffl'd;

A crafty servant whipp'd; a niggard churl

Hoarding up dicing-moneys for his son;

A spruce, fantastic courtier, a mad roarer,

A jealous tradesman, an o'erweening lady,

A corrupt lawyer-rightly personated;

18 Randolph, Works, I, 63.

19 Ibid., I, 183, The Muses' Looking-glass, I, 2.

20 Ibid., I, 185; The Muses' Looking-glass, I, 3. 
But (if we have a blush) will blush, and shame As well to act these follies as to own them." 21

Jonson himself nowhere expresses more plainly or more emphatically a belief in the didactic purpose of comedy to expose and scourge follies and vices.

Ward explains the purpose of The Muses' Looking-glass as the vindication of the moral power of comedy, ${ }^{22}$ and marks Randolph's difference here from Jonson in dispensing entirely with action and showing in a series of dialogues between abstract personages representing various vices and virtues, that practicable virtue is a mean between two extremes. The Jealous Lovers, The Muses' Looking-glass and Hey for Honesty, all contain many allusions to abuses and knaveries of the time. In the two latter plays, unjust and indifferent justices, proud and whimsical ladies, zealous saints of Amsterdam, corrupt churchmen, and flattering courtiers, are severely satirized. We hear again in The Muses' Looking-glass of the old project to drain the fens, and there also a proposal is made to found a free school in London to teach young gentlemen how to drink and take tobacco, swear, roar and quarrel.

The picture of the Puritans that we get in The Muses' Looking-glass is full of humor and interest, and is such skillful portraiture as Jonson had created models for in The Alchemist and Bartholomew Fair. Bird and Mistress Flowerdew, who serve the theater at Blackfriars with feathers and other small wares, express their abhorrence of playhouses; Roscius, the demonstrator of the action that we learned to look for in Jonson's comedies, joins them, prevails on them to see the play to be given, and, as it proceeds, explains its significance. Of all the later dramatists who followed Jonson's lead in satirizing the Puritans,

21 Ibid., I, 188-189; The Muses' Looking-glass, I, 4. 22 Ward III 135. 
no other has been so successful as Randolph here, and one or two passages are worthy of quotation:

Mistress Flowerdew. See, brother, how the wicked throng and crowd

To Works of vanity! Not a nook or corner

In all this house of sin, this cave of filthiness,

This den of spiritual thieves, but it is stuff'd,

Stuff'd and stuff'd full, as is a cushion,

With the lewd reprobate.

Bird. Sister, were there not before inns-

Yes, I will say inns, for my zeal bids me

Say filthy inns-enough to harbor such

As travel'd to destruction the broad way;

But they will build more and more-more shops of Satan?

Mis. Flo. Iniquity aboundeth, though pure zeal

Teach, preach, huff, puff, and snuff at it; yet still

Still it aboundeth. Had we seen a church,

A new-built church, erected north and south,

It had been something worth the wondering at.

Bird. Good works are done.

Mis. Flo. I say no works are good;

Good works are merely popish and apocryphal.

Mis. Flo. It was a zealous prayer

I heard a brother make concerning playhouses.

Bird. For charity, what is't?

Mis. Flo. That the Globe,

Wherein (quoth he) reigns a whole world of vice,

Had been consum'd: the Phœnix burnt to ashes:

The Fortune whipp'd for a blind whore: Blackfriars,

He wonders how it 'scap'd demolishing

I' th' time of reformation: lastly, he wish'd

The Bull might cross the Thames to the Bear Garden, 
And there be soundly baited.

Bird. A good prayer.

Miss. Flo. Indeed, it something pricks my conscience

I come to sell 'em pins and looking-glasses.

Bird. I have their custom too for all their feathers:

'Tis fit that we, which are sincere professors,

Should gain by infidels." ${ }^{23}$

Again :

"Mis. Flo. What do you next present?

Roscius. The several virtues.

Bird. I hope there be no cardinal virtues there!

Ros. There be not.

Bird. Then I'll stay. I hate a virtue

That will be made a cardinal : cardinal virtues,

Next to pope-virtues, are most impious.

Bishop-virtues are unwarrantable.

I hate a virtue in a morrice-dance.

I will allow of none but deacon-virtues,

Or elder virtues.

Ros. These are moral virtues.

Bird. Are they lay-virtues?

Ros. Yes.

Bird. Then they are lawful:

Virtues in orders are unsanctified.

Ros. We do present them royal, as they are

In all their state in a full dance.

Bird. What dance?

No wanton jig, I hope; no dance is lawful

But prinkum-prankum!

Mis. Flo. Will virtues dance?

0 vile, absurd, maypole, maid-marian virtue !" ${ }^{24}$

It is in the characters with their descriptive names, al-

23 Randolph, Works, I, 179-182; The Muses' Looking-glass, I, 1.

24 Ibid., 259-260; The Muses' Looking-glass, V, 1. 
legorical significance, and distinguishing humors that we trace most surely the direct influence of Jonson. Asotus of The Jealous Lovers in name and main characteristics owes much to Asotus, the citizen's heir and prodigal of Cynthia's Revels. Ballio persuades the Asotus of The Jealous Lovers to turn over his purse by convincing him that it indicates a lack of gentility to carry his own money, in much the same way that Amorphus inveigles the Asotus of the earlier play out of his new beaver. Ballio and Amorphus both tutor their rich, foolish and self-loving pupils in the art of compliment. As Asotus has the humor of spending, so his father has the humor of acquiring for the son on whom he dotes; Tyndarus and Techmessa, that of jealousy; and Dipsas, that of scolding. Edward Fraunces commends this comedy as a picture of humors:

"Pander, gull and whore:

The doting father, shark, and many more

Thy scene doth represent unto the life,

Beside the character of a curst wife:

So truly given, in so proper style,

As if thy active soul had dwelt a while

In each man's body and at length had seen

How in their humors they themselves demean." ${ }_{25}$

Ward considers The Muses' Looking-glass "an interesting illustration of the effect exercised upon literary minds of quick apprehension by the theories and examples which they found in Jonson's comedy of character," ${ }^{26}$ and Dr. Schelling finds here "especially the influence of Jonson's later revulsion to the methods and ideals of the old moralities." 27 The author declares frankly that he brings

25 Randolph, Works, I, 63.

26 Ward, III, 134 .

27 Schellino. II, 86. 
"No plot at all, but a mere Olla Podrida, A medley of ill-plac'd and worse penn'd humors. His desire was in single scenes to show How comedy presents each single vice Ridiculous." 28

We get abstract and yet witty, original and effective presentation of flattery and impertinence, overweening confidence and foolish distrust, vain ostentation and base penury, and many other excesses of virtue that have become vices.

In regard for classical rules of construction, in moral intent, in subject and quality of satire, and in characters of humors, Randolph's work has likenesses to Jonson's. Just how far these are due to Randolph's own classic bent and academic study, and how far to Jonson's direct influence, it is impossible definitely to decide. We can say, however, that in the follies and views he satirized and the humors he portrayed, Randolph certainly had accepted the teaching of Jonson.

Shakerley Marmion, having graduated from Oxford and afterwards tried his fortune as a soldier in the Low Countries, came to London to make his way as a man of letters and gained the patronage of Jonson. Brome, Heywood, and Nabbes were his friends and wrote verses for his Cupid and Psyche in 1637. In A Fine Companion there is a passage which seems to refer to the gatherings at the Devil Tavern:

\section{"AEmilia. Whence come you? from Apollo?}

Careless. From the heaven

Of my delight, where the boon Delphic god

Drinks sack, and keeps his Bacchanalias,

And has his incense, and his altars smoking,

28 Randolph, Works, I, 193-194; The Muses' Looking-glass, I, 4. 
And speaks in sparkling prophecies; thence do I come." ${ }^{29}$

For the Jonsonus Virbius, Marmion wrote verses "to the sacred memory of his thrice honored father," declaring that from Jonson's light "myself have lately received influence." ${ }^{30}$

Holland's Leaguer, A Fine Companion and The Antiquary were written in the thirties and are all comedies of manners and humors. That Marmion had an ethical purpose in mind when he began to write we know from the address to the reader before his earliest play, Holland's Leaguer: "However my muse has descended to this subject, let men esteem of her only as a reprover, not an interpreter of wickedness," for "former writers in their accurate discovery of vice, have mingled their precepts of wisdom. ${ }^{31}$ Philautus in this play is sick of self-love and his friend Fidelio sets out in the first act to find "a means to cure him of his folly." Here and there, through all these plays we find that expository satire which so many of his successors learned from Jonson. In Holland's Leaguer several characters rail against the ever-recurring abuse of bribery; projectors are once again scornfully satirized in accounts of their impossible schemes for making money; and the true gallant who promises anything, never pays, vows love to every fair lady he meets and talks idly all the day long, is described at length. Again, in The Fine Companion "the time's disease of compliment" is ridiculed, and also the vulgar idea concerning a lady that it is necessary for her to "have clients wait at her gates with presents and yet have their servile offices pass unregarded," "be as proud as she list and have new ways to express it," "ride

29 Marmion, Dramatic Works, 138; A Fine Companion, II, 4. 30 Jonson, Works, III, 515-516.

31 Marmion, Works, 5. 
up and down in her litter and have a coach and four horses to follow after, full of gentleman ushers and waiting women." ${ }_{32}$ The subject of watches to which Jonson himself refers several times comes up again in The Antiquary: "Petrutio. And now you talk of time, what time of day is it by your watch?

Lionell. I have none, sir.

Pet. How, ne'er a watch? Oh monstrous! How do you consume your hours? Ne'er a watch? 'Tis the greatest solecism in society that e'er I heard of: ne'er a watch?

Lio. How deeply you conceive of it!

Pet. You have not a gentleman, that's a true gentleman, without one; 'tis the main appendix to a plush lining: besides, it helps much to discourse; for, while others confer notes together, we confer our watches, and spend good part of the day with talking of it." ${ }^{33}$ These examples show that while Marmion did succeed in eatching something of Jonson's satirical tone, he simply rang the changes on subjects already overworked.

According to a passage in The Antiquary, Marmion held that "So many men, so many humors." Now and again a particular person in the comedies is pointed out as possessing or as evidencing in some way a characteristic humor, and many of the characters are named in accordance with their chief quality. Trimalchio in Holland's Leaguer is "a humorous gallant" and "a giant in conceit," who thus explains his name:

\section{"'my father's name}

Was Malchio, for my three additions

Of valor, wit and humor, 'tis enlarged

To Mr. Trimalchio." ${ }^{34}$

32 Marmion, Dramatic Works, 130; A Fine Companion, II, 2.

33 Ibid., 204; The Antiquary, I, 1.

34 Ibid., 28; Holland's Leaguer, II, 1. 
His wit is such that

\section{"it never fails me,}

I have it at a certainty: I'll set it

To run so many hours, and when 'tis down,

I can wind it up like a watch." ${ }_{35}$

He fights by geometry:

$$
\text { " I'll show you in geometry, }
$$

Two parallels can never meet: now we two

Being parallels, for so we are, that is

Equal in wit and valor, can never meet,

And if we never meet, we shall ne'er fight.", ${ }_{36}$

Spruce in A Fine Companion is a gallant who continually proffers but never performs courtesies, is a suitor to every woman he meets and keeps a bundle of blank loveletters ready to have names inserted. Lackwit of the same play harks back to Jonson's La-Foole tribe: "This is a book of heraldry, forsooth, and I do find by this book that the Lackwits are a very ancient name, and of large extent, and come of as good a pedigree as any is in the city; besides they have often matched themselves into very great families, and can quarter their arms, I will not say with lords, but with squires, knights, aldermen, and the like, and can boast their descent to be as generous as any of the La-Fooles or the John Daws whatsoever." ${ }_{37}$ Captain Whibble is another swaggering, blustering, swearing roisterer, called in one place, "Kastrill." Petrutio in The Antiquary is a follower of strange fashions and follies, who has traveled and therefore considers himself incomparable for judgment. The Antiquary, Veterano, as has already been pointed out, ${ }^{38}$ is the most novel of the per-

${ }^{35}$ Marmion, Dramatic Works, 46; Holland's Leaguer, II, 5.

36 Ibid., 91; Holland's Leaguer, V, 4.

37 Ibid., 142; A Fine Companion, II, 5.

38 Ward, III, 148, and Schelling, II, 276. 
sonages created by Marmion and a happy invention, though in the end left with the possibilities of the original conception undeveloped and unused. Veterano has directed all his powers in one direction toward the collection of old manuscripts and articles of various kinds until at length he has become exceedingly credulous. After drinking more wine than usual, he believes that he wears Hannibal's spectacles, Julius Cæsar's hat and Pompey's breeches, and is gulled into purchasing what he supposes a $D e R e$ publica in Cicero's own handwriting and a long lost book of mathematies restored by Ptolemy.

Though far from attaining his master's powers, it is evident from whom Marmion took lessons in conceiving and portraying character. The plays show a liking for Latin phrases and classical allusions that may have developed under Jonson's influence. The prologue to A Fine Companion consists of a dialogue between a critic and the author, such as Jonson frequently used, and, according to Ward, borrows part of its phraseology from Persius. ${ }^{39}$ The plots are made up of schemes for gulling or for purging, intrigues and tricks, neither especially clever nor original. Marmion sought to apply Jonson's general theories in plot, character and satire, and, however rigid in interpretation and lacking in originality the results may be, he did not slavishly imitate any particular play or plays.

William Cartwright, according to Wood, was "the most noted poet, orator, and philosopher of his time," and "the most florid and seraphical preacher in the university." ${ }_{40}$ Langbaine tells us that "the ablest judge of poetry at that time, I mean Ben Jonson, said with some passion, 'My son Cartwright writes all like a man.' "' 41 To the Jonsonus

39 Ward, III, 147.

40 Wood, Athen. Oxon., III, 69.

41 Langbaine, 53. 
Virbius he contributed a long elegy, addressing Jonson as "Father of poets." The earliest publisher of his poems exclaimed in admiration of this: "What had Ben said, had he read his own eternity in that lasting elegy given him by our author!" 42 Whether, however, it added much to Jonson's fame is a matter of great doubt.

Cartwright's one comedy of manners, The Ordinary, probably written in 1634, is a coarse and dull picture of the very lowest classes of London society and centers about a city restaurant of the time. That he has obtained his material at second-hand, the author himself admits in the prologue :

"That web of manners which the stage requires, That mass of humors which poetic fires Take in, and boil, and purge, and try, and then With sublimated follies cheat those men That first did vent them, are not yet his art;

Think, then, if here you find nought can delight, $\mathrm{He}$ hath not yet seen vice enough to write." 43

It is very evident that Cartwright in this play took as his model The Alchemist. Hearsay an intelligencer, Slicer a discharged lieutenant, and Shape a cheater, three sharpers, in imitation of Subtle, Face and Dol, form a confederacy to give mutual assistance. They choose an ordinary as their base of operations and here draw within their net various victims, among others a gamester Caster, who comes like Dapper to learn how to win unfailingly at cards and dice, and Have-at-all, who like Kastrill would know how to prove always valiant and victorious in a fight. In personages, situations and dialogues, the play is closely reminiscent of Jonson.

42 Langbaine, 55.

43 Dodsley's Old Plays, ed. by Hazlitt, XII, 209. 
The quarrel of Slicer, Hearsay and Shape with Widow Potluck in the first act seems to have been suggested by the violent dispute of Subtle, Face and Dol at the beginning of The Alchemist. The way in which the gang draws its victims and slyly dupes them out of their money is in direct imitation of the methods portrayed by Jonson. Take as illustration this passage:

"Caster. Do you think

I will betray myself or you, whom I

Esteem above myself? I have as yet

One hundred left, some part of which-

Shape. Faith, sir,

These lines require advice; if it should come

Unto the council's ear once, he might be

Sent into other kingdoms to win up

Money for the relief o' th' state, and so

$\mathrm{Be}$ as it were an honest kind of exile.

Cast. If I do e'er discover, may I want

Money to pay my ordinary: may I

At my last stake (when there is nothing else

To lose the game) throw ames-ace thrice together!

I'll give you forty pound in hand-

\section{Hearsay. I may}

Show you the virtue of't, though not the thing:

I love my country very well. Your high

And low men are but trifles; your pois'd dye,

That's ballasted with quicksilver or gold,

Is gross to this-

Shape. Proffer him more, I say.

Cas. Here's fifty-

Hear. For the bristle dye, it is

Not worth that hand that guides it: toys fit only

For clerks to win poor costermongers' ware with.

Shape. You do not come on well. 
Cas. Here's threescore-

Hear. Then

Your hollowed thumb join'd with your wriggled box-

The slur and such like are not to be talked of;

They're open to the eye. For cards, you may

Without the help of any secret word

Or a false hand, without the cut or shuffle,

Or the pack'd trick, have what you will yourself;

There's none to contradict you.

Cas. If you please

But to instruct me, here is fourscore pound.

Hear. Do you think 'tis money I esteem? I can

Command each term by art as much as will

Furnish a navy. Had you but five pound

Left you in all the world, I'd undertake

Within one fortnight you should see five thousand.

Not that I covet any of your dross,

But that the power of this art may be

More demonstrably evident, leave in

My hands all but some smaller sum to set,

Something to stake at first.

Shape. He'll tell you all,

If you but seem to trust him.

Cas. Here I'll lay

Down in your hands all but this little portion,

Which I reserve for a foundation.

Hear. Being y'are confident of me, and I

Presume your lips are sealed up to silence,

Take that, which I did never yet discover:

So help you fortune, me philosophy." 44

Compare this with the following from The Alchemist: "Subtle. Marry, to be so importunate for one

That, when he has it, will undo you all:

44 Dodsley's Old Plays, XII, 243-245; The Ordinary, II, 3. 
He'll win up all the money in the town.

Face. How!

$S u b$. Yes, and blow up gamester after gamester As they do crackers in a puppet-play.

Face. Do you think that I dare move him?

Dapper. If you please, sir;

All's one to him, I see.

Face. What! for that money?

I cannot with my conscience; nor should you

Make the request, methinks.

Dap. No, sir, I mean

To add consideration.

Face. Why then, sir,

I'll try. Say that it were for all games, doctor?

$S u b$. I say then, not a mouth shall eat for him

At any ordinary, but on the score,

That is a gaming mouth, conceive me.

Face. Indeed!

$S u b$. He'll draw you all the treasure of the realm

If it be set him.

Face. Go to. Go thank the doctor: he's your friend, To take it so.

Dap. I thank his lordship.

Face. So! Another angel.

Dap. Must I?

Face. Must you! 'slight,

What else is thanks? Will you be trivial?" 45

Caster's dream of what he will do with all the wealth that is to be his is based upon Sir Epicure Mammon's ecstasies of joy as he anticipates the possession of untold riches. Caster exclaims :

45 Jonson, Works II, 12-14; The Alchemist, I, 1. 
"First, will I beggar all the gentlemen

That do keep terms; then build with what I win.

Next I'll undo all gaming citizens,

And purchase upon that. The foreman shall

Want of his wonted opportunities;

Old Thomas shall keep home, I warrant him.

I will ascend to the groom-porters next,

Fly higher games, and make my mincing knights

Walk musing in their knotty freeze abroad;

For they shall have no home. There shall not be That pleasure but I'll balk: I'll run o'er nature; And when I've ransacked her, I'll weary art: My means, I'm sure, will reach it.

I'll send some forty thousand unto Paul's;

Build a cathedral next in Banbury;

Give organs to each parish in the kingdom;

And so root out th' unmusical elect.

I'll pay all soldiers whom their captains won't;

Raise a new hospital for those maim'd people

That have been hurt in gaming: then build up

All colleges that ruin hath demolish'd,

Or interruption left imperfect." ${ }_{48}$

Compare with this especially the following:

"Mammon, No, I assure you,

I shall employ it all in pious uses,

Founding of colleges and grammar schools,

Marrying young virgins, building hospitals,

And now and then a church." 47

The rogues, when alone, exult over the success of their schemes, glorying not only in the money they have gained

46 Dodsley's Old Plays, XII, 247-248; The Ordinary, II, 3.

47 Jonson, Works, II, 25; The Alchemist, II, 1. 
but almost as much in the fun they have had out of their tricks. They talk over what they have accomplished and repeat to one another with keen sense of humor the foolish utterances of their unsuspecting victims. All this is plainly reminiscent of The Alchemist and perhaps also of Volpone. All the sharpers at the end of the play escape by their cleverness the punishment they deserve. We are forced to admire their skill and judge them by an intellectual standard rather than a strictly moral one. Here again the influence of The Alchemist is clearly manifested. Ward suggests that the basis of the military dinner described in great detail, Act II, Scene 1, is to be found in the cook's speech in Jonson's masque, Neptune's Triumph. ${ }^{48}$

Cartwright refers slightingly to the Puritans a number of times in The Ordinary and shows that he has been impressed by Jonson's satire against them. We find this bit of doggerel in the play:

\section{"My name's not Tribulation, Nor holy Ananias : \\ I was baptized in fashion, Our vicar did hold bias." ${ }_{49}$}

The mercer's speech, liberally interspersed with "brother," "verily," and "truly," is intended as satire against the cant of the Puritans. In the final scene, Shape, Slicer and Hearsay go off to New England:

"Slicer. There is no longer tarrying here: let's swear

Fidelity to one another, and

So resolve for New England.

Hearsay. 'Tis but getting

A little pigeon-hole reformed ruff-

Slicer. Forcing our beards into the orthodox bent-

48 Ward, III, $140^{2}$.

49 Dodsley's Old Plays, XII, 280; The Ordinary, IV, 1. 
Shape. Nosing a little treason 'gainst the King,

Bark something at the bishops, and we shall

Be easily received.

Hear. No fitter place.

They are good silly people; souls that will

$\mathrm{Be}$ cheated without trouble. One eye is

Put out with zeal, th' other with ignorance;

And yet they think they're eagles.

Shape. We are made

Just fit for that meridian. No good work's

Allowed there: faith-faith is what they call for,

And we will bring it 'em.

Slicer. What language speak they?

Hear. English, and now and then a root or two

Of Hebrew, which we'll learn of some Dutch skipper That goes along with us this voyage." 50

Cartwright has imitated Jonson more closely than any of the followers previously studied. The confused coarse picture we get in The Ordinary but serves to throw into stronger relief the vigor and power of The Alchemist.

Jasper Mayne was an intimate friend of Cartwright, and like him was a divine, a royalist, a contributor to the Jonsonus Virbius, and the writer of one comedy in Jonson's manner. His translation of Lucian's Dialogues, 1638, is dedicated to Jonson's friend and patron, the Earl of Newcastle. The City Match, 1639, is as close an imitation of The Silent Woman as The Ordinary is of The Alchemist. -The address to the reader declares that the author did not court fame from the stage, and published his play only by way of self-protection that it might not in a false copy "appear to the world with more than its own faults." His aim was to present nothing

50 Dodsley's Old Plays, XII, 316-317; The Ordinary, V, 5. 
" But what was first a comedy i' th' street:

Cheapside brought into verse; no passage strange

To any here that hath been at th' Exchange." 51

And the play is full of allusions to well-known places and localities in London such as the Temple, the Exchange, the Strand, Fleet Street, the Mermaid, St. Paul's or Westminster Hall.

Warehouse, the miserly uncle, corresponds to Morose in The Silent Woman; Frank Plotwell is another clever Dauphine; Bright and Newcut are slight copies of Truewit and Clerimont; Bannswright fills the office of Cutbeard in obtaining a wife for the old uncle who is to be duped; and the "philosophical madams" are later representatives of the "ladies collegiate." Warehouse, utterly out of conceit of his wild and extravagant nephew, resolves to marry and disinherit the scapegrace. To prevent the marriage, the same sort of device used in The Silent Woman is resorted to, but modified in that he is married by a mock priest to a girl already wedded to the nephew. The speech in which Warehouse asserts his determination to marry immediately is modeled after that of Morose when he has decided to take a like step. There are similar threats, similar plans, and similar chuckles of delight over the anticipated confusion of the disappointed nephew. After marriage, there is a like sudden transformation of the wife from a quiet timid girl to a loud-voiced dictatorial shrew. Situations and dialogue afford here close parallels. Warehouse, like Morose, is driven to the thought of suicide. Plotwell assures speedy relief to the harassed uncle in return for a promise of reward, written, signed and sealed, in imitation again of Dauphine's procedure. The entire second half of the play is patterned throughout after Jonson's great comedy.

51 Dodsley's Old Plays, XIII, 319; Epilogue to The City Match. 
Many of the minor imitations in descriptions, jokes and allusions have already been pointed out by Miss Henry in her edition of Epicone.52 Take, for instance, the description of the widow in The City Match:

"some old widow, which at every cough Resigns some of her teeth, and every night Puts off her leg as duly as French hood, Scarce wears her own nose, hath no eyes but such As she first bought in Bread Street, and every morning, Is put together like some instrument." ${ }_{53}$

Compare this with Tom Otter's description of his wife: "All her tceth were made in the Blackfriars, both her eyebrows in the Strand, and her hair in Silver Street. Every part of the town owns a piece of her. . . . She takes herself asunder still when she goes to bed, into some twenty boxes; and about next day noon is put together again, like a great German Clock." ${ }_{54}$ Anything but attractive these descriptions certainly are, but they serve to show how minutely Mayne again and again followed Jonson. Miss Henry refers the account of monstrosities in The City Match, Act III, Sc. 1 to Epiccene, Act II, Sc. 1, but the latter is simply a reference to "masques, plays, Puritan preachings, mad folks, and other strange sights." There seems to be a more direct parallel here with The Alchemist, Act V, Sc. I, where there is a like enumeration of particular strange sights.

Mayne does not forget to take his turn at satirizing the Puritans. The requirements for becoming one of them are defined as the ability to turn up the eyes, "speak in the nose, draw sighs of an ell long, and rail at discipline." Dorcas, who in the progress of the plot is married to 52 Yale Studies in English, XXXI, 1906; Introduction, LVIILVIII.

53 Dodsley's Old Plays, XIII, 237; The City Match, II, 4.

54 Jonson, Works, I, 438; The Silent Woman, IV, 1. 
Warehouse, assumes for disguise the dress, speech and manner of a Puritan, and then serves as a lady's maid. Her mistress complains of her:

\section{"I am never dress'd}

Without a sermon; but am forc'd to prove

The lawfulness of curling-irons, before

She'll crisp me in a morning. I must show

Texts for the fashions of my gowns. She'll ask

Where jewels are commanded? or what lady

I' th' primitive times wore ropes of pearl or rubies?" ss

Two satirical references are made to "the new heresy, Platonic love." The ridicule with which the popular eagerness to see abnormal and unusual objects is portrayed has already been mentioned. Two scenes are devoted to the exhibition by a crowd of wits of a simple gull as a man-fish.

The City Match is a clever and interesting imitation of The Silent Woman, and Mayne is here largely indebted to Jonson for plot, characters and satire.

In Henry Glapthorne for the first time in this study we come to a man between whom and Jonson there is no evidence of any direct personal relation. We do not know that Jonson ever called him "Son," or even received from him complimentary verses. The testimony of his plays must then be wholly depended upon to justify the assignment to him of a place in the present group of writers. Beyond the fact that like Marmion, Cartwright and Mayne he devotedly supported the royal cause, practically nothing is known of his life. He wrote several tragedies and tragicomedies, following the manner of Fletcher and Shirley; but the plays with which we are chiefly concerned here are two comedies of manners, The Hollander and Wit in a Constable, both belonging to the thirties, one acted in 1635 and the other in 1639. The Ladies' Privilege, an heroic play,

ss Dodsley's Old Plays, XIII, 226; The City Match, II, 2. 
1640 , contains also several characters conceived on the basis of humors.

We find here not the same direct imitation of particular plays, characters and passages that appeared in the comedies of Cartwright and Mayne, but such more general influence on plot, personage and satire as characterized the work of Marmion. The same ever recurring fads, follies and abuses are satirized; the same old kinds of tricks and schemes are affected; the same familiar types of character are presented.

In The Hollander the group of roarers call themselves the "Twibill Knights"; the rules of the order are set forth at length; and the initiation of a foolish coxcomb into the brotherhood is satirically portrayed. Reference is scornfully made in both The Hollander and The Ladies' Privilege to the "precise precisians." The Hollander and Wit in a Constable return to the overworked subject of monopolies, and both refer slightingly to the Puritans. The make-up of the woman of fashion is ridiculed in The Holtander, and the abuse of fees and bribes deplored in the same play. Both subject and manner of satire are such as we have already become thoroughly acquainted with in Jonson's imitators.

The Hollander and Wit in a Constable both have their scenes laid in London, and both present coarse pictures of the life of the city with many allusions to well-known places. The plots have the usual network of trickery and roguery. In The Hollander, a doctor and his wife set out to gull all who come within their range, and after various intrigues, projects and counter-projects, are themselves gulled in the marriage of their daughter contrary to all their plans. Wit in a Constable affords one or two new situations and the plot is developed eleverly and interestingly. Jeremy Holdfast, who has been assuming scholastic tastes and seeking "to be esteemed by his volumes," 
is persuaded by Thorowgood to turn city gallant. Thorowgood himself then approaches the uncle of the girl intended for Holdfast, and by his learned vocabulary and pedantic cant deceives that admirer of those who "speak learnedly" "metaphors and tropes scholastic."

The principal character of humors in The Hollander is Sconce the Hollander, another member of the La-Foole tribe. "My name," he says, "is Sconce, sir, Master Jeremy Sconce. I am a gentleman of a good family, and can derive my pedigree from Duke Alva's time; my ancestors kept the inquisition out of Amsterdam." ${ }^{68} \mathrm{He}$ is duped to believe in a "weapon salve" which, when applied to the iron or steel that has produced a wound, will heal immediately an injury however great. There is a likeness here to a Jonsonian character in Shirley's The Young Admiral-Pazzarello, who was led to believe that he had been made invulnerable. In the satirical drawing of Sconce, we see a hatred of the Dutch, manifested in a number of plays written about the same time as The Hollander. The humor of Alderman Covet in Wit in a Constable is a foolish admiration for pedantry; and that of Busy, a pride in his own wit. The charge which the constable gives to his men, as has been frequently noted, is plainly an imitation of that delivered by Dogberry in Much Ado About Nothing. Other characters of humor are Jeremy Holdfast in his rapid transfiguration from a pretended pedant to a gay gallant; and Sir Timothy Shallowit, who has come up from the country to change his "ancient garment to a new one of a more spruce edition" and whose unvarying phrase of assent is "very right." Frangipan of The Ladies' Privilege always brings news already known and "relates things by tradition as dogs bark"; Corimba, a woman of the court, goes about provided with material to cut at a moment's notice for any one's face a patch in the shape of a heart;

56 Glanthorne Dramatic Works I 85: The Hollander. I, 1. 
and Adorni has a humor for imitating whatever humors in other men appear to him laughable and ridiculous.

Such are the satire, plots and humorous characters of Glapthorne's comedies. We have come a long way from Jonson's vigorous characters, skillfully executed plots and trenchant satire, but it is not difficult to trace the line of descent.

Thomas Nabbes again was a gentleman, a scholar, a member of court circles, and a loyal friend of the Stuarts. Like other play-writers of this group, he tried his hand at several kinds of drama, classical tragedy, masque, and comedy of every-day life. Three such comedies, written in the thirties, entitle him to a place here. Complimentary verses give testimony of his friendship with Shakerley Marmion and Richard Brome, and while there is no direct evidence of association, yet he surely must have known Jonson. There is a reference to Jonson in Tottenham Court where one of the characters cries out: "Give me Jonson and Shakespeare; there's learning for a gentleman." ${ }_{57}$

In the prologue to Covent Garden Nabbes lays claim to originality and declares that he offers

\section{"no borrow'd strain}

From the invention of another's brain;" ss

and Langbaine supports this claim: "what our author has published is his own and not borrowed from others." 59 Nabbes does have individuality of his own, and his freedom from coarseness, first-hand observation of life, naturalness of character and dialogue, bring a welcome relief from the plays of the three or four preceding writers. Bullen comments on Nabbes' "virtuous and refined gentlemen" and "modest, well-conducted girls, devoted to their lovers and

57 Bullen's Old Plays, New Series, I, 133; Tottenham Court, III, 1. 68 Ibid., I, 5.

69 Langbaine, 379. 
courageous in the face of difficulties," serve the commendation given them. To assert that Nabbes was influenced by Shirley and Jonson does not involve the denial of his possession of originality. Bullen gives him his "place at the feet of Shirley on the lower slopes of Parnassus," for "he has much of Shirley's fluency and refinement." A1 A study of the three comedies, Covent Garden, Tottenham Court and The Bride proves also the presence of Jonson's influence.

Directly or indirectly the construction of these plays points back to Jonson. There is comparative regularity, and the action takes place within a few hours in London and its environs. The epilogue to Covent Garden declares this a play

$$
\text { "wherein was no disguise, }
$$

No wedding, no improbable devise;

But all an easy matter, and contain'd

Within the time of action." 62

The plots include "projects" to "gull" and intrigues of various kinds, some of them clever and inventive. Covent Garden, Tottenham Court and The Bride all portray everyday London life and contain many allusions to such wellknown places as Middlesex, Tyburn, Ludgate or Bridewell, and interesting descriptions of contemporary customs. Here is some information from Covent Garden about the methods of strolling players :

"Dobson. But tell me, Ralph, are those players the ragged fellows that were at our house last Christmas, that borrowed the red blanket off my bed to make their mayor a gown; and had the great pot-lid for Guy of Warwick's buckler?

oo Bullen, I, XIV.

61 Ibid., I, XX.

62 Ibid., I, 91. 
Ralph. No, Dobson, they are men of credit, whose actions are beheld by every one, and allow'd for the most part with commendations. They make no yearly progress with the anatomy of a sumpter-horse, laden with the sweepings of Long-Lane in a dead vacation and purchas'd at the exchange of their own whole wardrobes. They buy not their ordinary for the copy of a prologue, nor insinuate themselves into the acquaintance of an admiring ningle, who for his free coming in is at the expense of a tavern supper, and rinses their bawling throats with Canary." 83

Nabbes is not wholly free from didactic purpose. In the dedication of Tottenham Court he censures the vulgar "who please their senses oftener with show than their intellects with the true moral end of plays, instruction." ${ }_{64}$ Several times he expressly points out that he is whipping vice and folly with "satire," and scattered through all three plays are well-written moral observations and maxims on right means to an end, temperance, good judgment, avoidance of scandal, honesty and like subjects. Sir Generous Worthy in Covent Garden is "purged" of his "humor" of jealousy as are other characters of their corresponding follies. We find no new objects of satire, but the familiar ridicule of projectors, bribe-takers, fashionable courtiers and superficial gentlemen, roarers, and Puritans.

The theory of humors is applied most fully in the characters of Covent Garden. Dungworth desires to sell his acres, buy a knighthood and turn gallant; Susan, a waiting-woman, is greatly addicted to sack which never fails to produce in her a "loving humor," so that she courts every man she meets; Warrant and Spruce, "Knight of the Inkhorn"' and "Knight of the Spanish Needle," boastfully

63 Bullen's Old Plays, New Series, I, 9; Covent Garden, I, 1. 64 Ibid., I, 95. 
challenge each other to a duel but prove complete cowards; Littleword, true to his name, stands speechless before the lady he would win; and Mistress Tongall, the gossip, has an unlimited supply of words and offers to every man on every possible occasion her daughter Jinny as a reward of any courtesy or service whatsoever. Nabbes seems to have realized the artificiality of such a method of constructing character even while he made use of it, and caused Mistress Tongall to say of some one who is watching her: "'Tis his practice of observation. He is taking a humor for a play; perhaps my talking of my daughter Jinny." ${ }_{65}$

The chief humorous character of Tottenham Court is the fantastic gallant, Changelove, "the Proteus of affection" with "as many shapes of love as there are objects." In The Bride we find a group of roarers; an antiquary absorbed in his collection of rarities and antiquities; Plaster, "the learned surgeon that speaks nothing but Latin, because either he would not be understood or not contradicted"; and Mrs. Ferret, a rarely obedient wife to the public ear and eye, but in private a shrew of shrews and complete master of her husband. She changes her tone with amazing rapidity when she addresses him in asides:

"Goodlove. Mr. Justice Ferret,

This was a large expression of your love

To come over the water.

Ferret. 'Twas my wife's desire.

Good. Kind Mistress Ferret!

M. Fer. Sir, the respects I bear you, and the obedience I owe my husband that commanded it, brought me over willingly to offer my service to so noble a friend. Good. Your courtesies overcome me. M. Fer. - A rot on the best linings of your three pil'd durable, your everlasting almanac of high days, os Bullen's Old Plays, New Series, I, 71; Covent Garden, IV, 5. 
feasts and sessions; was it my desire? Thou liest, thou wrong side of a lawyer turn'd outwards: I had better business at home. I could have seen if Mother Whirl had spun the last pound of flax I sent her, or called at Knock's the weaver's for my new napkins. I have no maids to cudgel their tasks out of. Indeed I can hardly keep any for such a goat as thou art.

Good. Are you offended with your husband, Mrs. Ferret? M. Fer. Obedience forbid it; my head, or if I may use the honorable phrase here without offense, my cap of maintenance.

Fer. No, no, sir; she was but excusing a few faults. M. Fer. - How, sir bubber, must the world take notice by you that I have faults or modesty to excuse them?", 68

Bullen characterizes Mrs. Ferret as "quite a Jonsonian figure recalling the immortal Mrs. Otter." 67

Nabbes was no slavish imitator, but in construction, realistic portrayal of contemporary life, moral satire, and characters of humors, his comedies show clearly results of Jonson's general influence.

Sir Aston Cockayne seems to have felt the influence of Jonson as diffused in the dramatic atmosphere of the time rather than to have consciously studied and accepted his theories in any such way as did "Sons" like Randolph, Marmion, Cartwright, Mayne or the Duke of Newcastle. Cockayne was a gentleman, educated in both universities, much traveled abroad, and extensively connected with the gentry and nobility of his time. Wood says of him that "he was esteemed by many an ingenious gentleman, a good poet and a great lover of learning, yet by others a perfect boon fellow, by which means he wasted all he had." $88 \mathrm{He}$

60 Bullen's Old Plays, II, 15-16; The Bride, I, 4.

o7 Ibid., I, XVII.

os Wood, Athen. Oxon., IV, 129. 
knew intimately many contemporary poets and dramatists, and had seen Jonson. He writes of "my good friend old Philip Massinger," 0 and tells us elsewhere that "Donne, Suckling, Randolph, Drayton, Massinger, Jonson, Chapman, and Holland I have seen." 70 There is a general reference to Jonson in the prologue to The Obstinate Lady:

\section{"for if y' are come to-day}

In expectation of a faultless play

Writ by learn'd Jonson, or some able pen

Fam'd and approv'd of by the world, you then

We disappoint." 71

Cockayne wrote some short poems, a masque, a translation of an Italian romance, a tragedy, a tragi-comedy, and a comedy. The Obstinate Lady, dating $1638^{72}$ or 1639 , as has been noticed by several critics, owes its greatest debt in plot and incident to Massinger, Beaumont and Fletcher. ${ }^{73}$ In the characters alone are to be found traces of Jonson's influence. The "humor" of Lucora, the obstinate lady, is a resolve never to marry; Phyginois is ever ready to utter a speech of meaningless eloquence, "a wordy nothing"; and Lorece, a fantastic gallant, is the "poetical servant" of a rich widow. The similarity of Lorece's account of his travels, Act II, Scene 1, to a narrative of imaginary experiences by Freshwater, a Jonsonian character, in Shirley's Ball, has been pointed out. ${ }^{74}$ In the tragi-comedy, Trapolin, there are many references to the "humor" of the good-natured, fun-loving buffoon who gives title to the play and is through magic made to look like the Duke of Tuscany.

69 Eng. Stud., XIV, 56.

70 Randolph's Works, I, XII.

71 Cockayne, Dramatic Works, 21.

72 Fleay dates 1031, but Schelling, 1638 or 1639, on account of reference to Brome's Antipodes of 1638 .

73 Cockayne's Dramatic Works, 18-19.

74 Schelling, II, 282. 
All these are characters of humors, sketched and outlined, though not carefully nor fully developed.

It is not as a dramatist that William Cavendish, Duke of Newcastle, is usually remembered, but as a loyal adherent of the Stuart kings in the Civil War and as a munificent patron of contemporary men of letters. He was also a great lover and master of the "art of manage". and wrote two celebrated treatises on horsemanship. "No person since the time of Augustus," says Langbaine, "better understood dramatic poetry nor more generously encouraged poets; so that we may truly call him our English Maecenas." 75 Shirley, Davenant, Dryden, Shadwell, Flecknoe and Congreve, all received favors from him; but to none does he seem to have performed more fully and heartily the office of friend and patron than to Jonson. This poet wrote verses in praise of the Duke's riding and fencing, epitaphs for various members of the family, an interlude for the christening of his son Charles, and two masques, Love's Welcome at Welbeck and Love's Welcorne at Bolsover, for entertainments given by him to the King and Queen. The Duchess in her Letters reports that her husband said he had "never heard anyone read well but Jonson." "76 Two references to the Devil Tavern are made in The Country Captain and perhaps the Duke sometimes joined there the group of comrade-wits gathered about Jonson.

A number of letters from Jonson to the Duke testify to the admiration and gratitude with which he regarded his generous benefactor. The following, written about 1628, when he was suffering from poverty and sickness, makes an appeal for assistance:

"My noblest Lord and best Patron,

I send no borrowing epistle to provoke your lordship, for 75 Langbaine, 386.

${ }^{76}$ Letters, quoted by Ward, II, 3211. 
I have neither fortune to repay, nor security to engage, that will be taken; but I make a most humble petition to your lordship's bounty to succor my present necessities this good time of Easter, and it shall conclude all begging requests hereafter on the behalf of your truest beadsman and most thankful servant, B. J." 77

Another letter was written in response to the Duke's request for a copy of some complimentary verses addressed to Jonson by admirers:

"My noblest Lord and my Patron by excellence,

I have here obeyed your commands and sent you a packet of my own praises, which I should not have done if I had any stock of modesty in store:-but "obedience is better than sacrifice," - and you command it. I am now like an old bankrupt in wit, that am driven to pay debts on my friends' credit; and for want of satisfying letters to subscribe bills of exchange.

Your devoted

4th Feb. 1632.

Ben Jonson." 78

Later, Jonson sent him, for reading and criticism, part of a book now lost, and began the accompanying letter thus :

"My Lord,

The faith of a fast friend with the duties of an humble servant, and the hearty prayers of a religious beadsman, are kindled upon this altar to your honor, my honorable lady, your hopeful issue, and your right noble brother, be ever my sacrifice." "79 The following is part of a letter that probably accompanied Love's Welcome at Welbeck:

"My noble Lord and my best Patron,

I have done the business your lordship trusted me with;

77 Jonson's Works, ed. by Cunningham, I, p. CXXXIV.

78 Ibid., I, CXXXV.

70 Ibid., I, p. CXXXVIII. 
and the morning after I received by my beloved friend, Master Payne, your lordship's timely gratuity-I style it such, for it fell like the dew of heaven on my necessitiesI pray to God my work may have deserved it; I meant it should in the working it, and I have hope the performance will conclude it. In the meantime, I tell your lordship what I seriously think-God sends you these chargeable and magnificent honors of making feasts, to mix with your charitable succors, dropt upon me your servant; who have nothing to claim of merit but a cheerful undertaking whatsoever your lordship thinks me able to perform." 80

Not only did the Duke of Newcastle turn to Jonson for the composition of masques to be used in entertainments to the King and Queen, but, when for his own amusement he tried his hand at writing plays, he sought guidance and direction from the same source. Langbaine gives his testimony that the Duke "had a more particular kindness for that great master of dramatic poesy, the excellent Jonson; and 'twas from him that he attained to a perfect knowledge of what was to be accounted true humor in comedy." 81 Richard Brome wrote in some verses "To my Lord of Newcastle on his play called The Variety, he having commanded to give him my true opinion of it," as follows :

"I would depose each scene appear'd to me An act of wit, each act a comedy, And all was such, to all that understood,

As knowing Jonson, swore by God 'twas good." 82

Of direct references to Jonson's work within Newcastle's plays, there is but one, a passing allusion to The Alchemist in The Country Captain.

Four comedies are ascribed to the Duke of Newcastle: 80 Jonson, Works, I, CXXXIX.

81 Langbaine, 386.

82 Brome, Works, II, 179. 
The Country Captain, The Variety, The Humorous Lovers and The Triumphant Widow. The latter two have not been available for the present study, and furthermore, were acted after the Restoration. The former were printed together in 1649 , but acted at Blackfriars in 1639 or $1640 .^{83}$ In the plot of The Country Captain may be traced reminiscences of Shirley rather than of Jonson, and we are constantly reminded of situations and devices in The Witty Fair One, The Wedding, Hyde Park and The Lady of Pleasure. Not only in the plot but also in the class of society portrayed, the dialogue, the quality of the humor, and the style of certain passages, the influence of Shirley is manifest. Wood has told us that this dramatist assisted the Duke in the composition of certain plays. ${ }^{84}$ Indeed, The Country Captain was for a time ascribed to Shirley, but has been proved to belong unquestionably to Neweastle. The Variety, on the other hand, bears no marks of Shirley's influence. Ward thinks it the better play, but in the present writer's judgment it is not nearly so interesting nor so well-constructed. Madame Voluble's school of fashion, with lectures on dress and manners, is another imitation of Wittipol's discourses in The Devil is an Ass. The group of humorists gathered about Lady Beaufield, a "lady of spirit and entertainment, the only magnetic widow i' th' town," 85 may have been suggested by the group centered around Lady Loadstone in The Magnetic Lady.

The Duchess says of her husband's purpose in these plays that "his chief design in them is to divulge and laugh at the follies of mankind; to persecute vice and to encourage virtue." se In The Country Captain the author shows folly as folly and vice as vice with sane and true moral sense; two of the principal characters at the end of the play de-

88 Fleay, I, 48.

84 Wood, Athen. Oxon., III, 739.

85 Newcastle, The Variety, 1649, p. 2; I, 1.

80 Life, ed. by C. H. Firth, 1886, pp. 201-202. 
clare themselves "cured" of wrongful purposes, and minor personages as a result of their folly and stupidity are thoroughly "gulled"; yet the fundamental intent does not seem to be essentially didactic any more than in Shirley's comedies. The Variety, in plot and general tone, is more frankly satirical and more rigidly punishes each character according to his deserts. Jeering, news-collecting, slavish following of fashions, indiscriminate knighting, and superficial assuming of a humor are warmly ridiculed. A bit of sixteenth century satire on "learned women" deserves to be quoted:

"Newman.-But these ladies are very tedious; we must have this lecture put down.

Sir William. They are more like to purchase Gresham College, and enlarge it for public professors. You may live to see another university built, and only women commence doctors." 87

But it was chiefly in the construction of his characters that Newcastle followed the lead of Jonson. In The Country Captain another representative of the Matthew type is found in Monsieur Device, who is "an English monsieur made up by a Scotch tailor that was prentice in France," and a master of compliment who dresses himself out in colored ribbons to express the varying states of hopes and fears in his affections, and above all, composes wonders in verse. Underwit, an interesting variation of Stephen in Every Man in His Humor, has been made captain of the train-band, so feels it "honorable" to forget his best friends, refuses to answer to "master," and orders his servant to go birding each morning about the house and shoot pigeons that he may get used to the noise of shot. Captain Sackbury is again an imitation of Bobadil, a lover of sack, "that wears

87 Newcastle, The Variety, 1649, p. 20; II, 1. 
no money in his scarlet hose, and when he is drunk is inflicted with counsel." He undertakes to teach Underwit wars and fortifications, and having beaten his pupil after too liberal a portion of sack, requires that foolish youth to ask his pardon for the beating. Engine, who proposes to make a patron rich by a monopoly of periwigs, recalls the projector Meercraft and his assistant Engine in The Devil is an Ass.

The idea of humors is prominent throughout The Variety. The author by frequent use of the word insists that we shall not fail to realize that humors are being portrayed. Manly, with his fancy for wearing the habit of Leicester and singing old songs, illustrates the humor that is superficial or temporarily assumed: Simpleton's one great desire is to be a gentleman; Sir William is in pursuit of a wealthy wife; Galliard considers it the most important thing in the world to be able to bow properly and dance gracefully; Formall has a capacity for news-gathering that would entitle him to a place in Jonson's Staple of News, and like Sir Politick Would-be in Volpone is acquainted with secrets of court and state which he imparts confidentially to any willing listener; Lady Beaufield wishes above all else to know the latest fashions; the Jeers, Major and Minor, have the method of jeering reduced to a system and hold it a certain means of accomplishing any undertaking.

In several familiar situations, in the use of moral satire, but chiefly in the characters of humors, do we find proofs that the Duke of Newcastle in writing his comedies accepted the teaching of Jonson.

With Sir William Davenant we end our study of "Sons of Ben" in English comedy before the Restoration. $\mathrm{He}$ forms a connecting link between the drama before the closing of the theaters in 1642 and after the return of Charles II, and is chiefly known for his part in the development of 
the Restoration heroic play out of the Fletcherian tragicomedy. However, Davenant's method was eclectic, and while he was decidedly a follower of the romantic school, yet, like Beaumont and Fletcher, Shirley and Massinger, he did not disdain to learn somewhat from Jonson, and to apply the theory of humors in one or two plays. He began his dramatic career in 1629 , the year that Jonson bitterly realized in the failure of The New Inn that he had lost his hold on the stage. There remains no evidence of direct personal relation between the two poets. Sixteen months after the death of Jonson, in 1638, Davenant was appointed as his successor in the poet-laureateship, and this office he held under both Charles I and Charles II. Thomas Peck in an epigram to Davenant joins his name with that of Jonson:

"That Ben, whose head deserved the Roscian bays, Was the first gave the name of works to plays:

You, his corival, in this waspish age, Are more than Atlas to the fainting stage." 88

On his grave, in imitation of the famous epitaph to Ben Jonson, was written, "O rare Sir William Davenant!"

Some slight influence of the Jonsonian satire may be detected in Davenant's work. The Wits and News from Plymouth, both dating from the first half of the thirties, contain bits of expository satire against wits, news-gatherers, takers of bribes, Puritans, silenced ministers and academics. In The Wits there is brought about a "conversion" of the Elder Palatine and Sir Morglay Thwack, two country gentlemen who have foolishly leased out all their lands and rents for pious uses and have come to town to live by their wits. The Platonic Lovers, 1636, aims throughout to ridicule the fashionable court fancy of the time, Platonic love.

It is in the characters of The Wits and News from 88 British Bibliographer, II, 312. 
Plymouth that we find surest evidence of Jonson's influence. Palatine the Elder and Sir Morglay Thwack of the former play have unbounded confidence in their own wit and their ability to live by it; Sir Tyrant Thrift is governed wholly by avarice; Snore, the constable, puts to sleep his sense of justice under the persuasive influence of money and wine. More Jonsonian are Sir Solomon Trifle, Sir Furious Inland, and Lady Loveright of News from Plymouth. Lady Loveright's "humor" is for a husband without money or learning. Sir Furious Inland has a most belligerent "humor," is "subject to the disease of quarreling" "and ready always to beat any one with or without provocation." Sir Solomon Trifle recalls Justice Clack of Brome's $A$ Jovial Crew:

\section{"He's a Justice of Peace,}

And in his country, custos rotulorum;

$\mathrm{He}$ can give a charge to the jury at Quarter-Sessions,

And tell aforehand what will be their answer;

To all his fellow justices he speaks gravely,

And will hear none but himself." 80

"The perpetual motion is in his tongue," and he does not hesitate to interrupt all speakers with "give me leave", or "this you would say" and to set forth at length what he considers himself better able to express. By means of his group of intelligencers, Scarecrow, Zeal and Prattle, he sets up a staple of news, gathers and distributes "news of all sorts and sizes" and can furnish complete information about "the designs of Europe."

Perhaps Davenant was unconscious of being in any sense a follower of Jonson, so thoroughly had the satiric tone and the conception of character on the basis of humors, introduced in Every Man in His Humor, become accepted phases of later dramatic method. $1,2$.

89 Davenant, Dramatic Works, IV, 118; News from Plymouth, 


\section{CHAPTER V}

\section{CONCLUSION}

The preceding studies convince us of the extent and importance of Ben Jonson's influence in the history of English drama. Few writers of comedy between 1598 and 1642 remained wholly unaffected by his striking plays as produced on the stage, and his dramatic theories so forcefully preached on every possible occasion. Mr. Fleay in the introduction to his Chronicle of the English Drama bears the following testimony to Jonson's position and power: "I cannot pass over in silence one point which has been impressed on me at every step in this long labor-the central importance of Ben Jonson . . . I have . . . studied Jonson deeply, and I do not exaggerate when I say that, although Shakespeare is the central figure in our dramatic literature, Jonson certainly is the central figure in our dramatic history.". 1

In comedy, Jonson's immediate contemporaries were influenced chiefly by his theory of humors and his ideal of constructive excellence. Chapman, Marston, Shakespeare, Beaumont, Fletcher, Massinger, Shirley, and one or two anonymous writers, all made some trial of humors in creating character, with success varying from the mere sketches of humorous personages in Marston's comedies or in the anonymous Every Woman in Her Humor to Shakespeare's Malvolio and the group of humorists centering about Falstaff. Shakespeare, however, was affected only superficially, for he divined at once that such a method might serve occasionally as foil for truer art, but was, in no wise,

1 Fleav. Chronicle of the English Drama, I, 13. 
to be universally applied. Beaumont and Fletcher, Massinger and Shirley, owe not a little of their power in conducting skillfully involved plots and in gaining unity of impression to Jonson's precept and example concerning logical construction. Whether by parallel development or direct influence, Chapman and Marston stand in close relation to Jonson, not only in their characters and plots, but also in scholarship, conscious effort, satire and reflective wisdom. Beaumont, Massinger and Shirley owe something to him in their satirical pictures of contemporary life. Beaumont's regular versification and some of Shirley's prologues also point back to him. However, all these writers cared too much for the favor of the public to adopt to any great extent Jonson's attitude of independence and arrogance; they were too keenly alive to the essential requirement that drama shall present character in action, to make frequent use of his expository method; and they well knew that the aim of a play should not be primarily ethical. They were great enough as playwrights to seize and put to their own uses with original power Jonson's most valuable discoveries in character and construction.

While the immediate contemporaries were professional playwrights and rival comrades, most of the later "Sons" were gentlemen, graduates of the university, members of the court circle, and acknowledged disciples. While the former for the most part accepted only a general influence from Jonson's best characteristics, the latter sought to follow him more closely and less wisely, often even in his faults of pedantry, caricature and didacticism. Among the "Sons," Brome must be given the foremost place by reason of his large number of comedies, and his conscientious, often by no means unsuccessful effort to conform to all the rules of Jonsonian art. The other "Sons," according to the manner and extent of the influence felt, fall into a number of groups. May and Randolph were themselves faith- 
ful students of the classics, and so their moral purpose, satire, plots of intrigue and characters of humors are probably in part due to their own direct study and in part to their admiration for Jonson. Field, Marmion, Glapthorne, and Nabbes, all show the effects of a general Jonsonian influence on their plots, personages and subjects of satire, in contrast with Cartwright and Mayne, who slavishly imitate particular Jonsonian plots, characters and satirical passages. Among these writers, Field and Nabbes stand out above the others, Field because of his practical skill in stagecraft and keen satirical pictures of London life, and Nabbes because of his pleasing style, refreshing freedom from coarseness and first-hand touch with real life. Newcastle turned to Jonson for much suggestion in the way of situation, satire, and character, but did not, like Cartwright, go so far as to copy directly a particular play. Davenport, Cockayne and Davenant, in plays otherwise free from Jonson's influence, apply the theory of humors in characterization.

Every writer who gained anything from Jonson was affected first and foremost by the idea of humors. The creation of new humorous types we have found in the plays of such men of genius as Shakespeare, Fletcher, Beaumont or Shirley, and even in those of Brome; but on the other hand, in the work of lesser men, there is an unending repetition of certain definite types patterned after Jonson's personages. Stephen, the country gull; Matthew, the foolish versifier; Bobadil, the braggart soldier; Fastidious Brisk, the fashionable gallant; Sir Amorous La-Foole, proud of his aneestry of fools; Mrs. Otter, the shrew ; Kastrill, the quarrelsome boy; Meercraft and Engine, the projectors; Fitzdotterel, a prey to sharpers; Tribulation Wholesome, Ananias, and Zeal-of-the-Land Busy, the hypocritical Puritan fanatics; Sir Politick Would-be, dealer in sensational news: -these recur in play after play and writer after writer, 
sometimes with enlivening variation, but often with wearisome sameness.

While Beaumont, Massinger and Shirley were incited by Jonson's ethical aim to a deeper moral earnestness and an effective satirical portrayal of actual contemporary life, such writers as Marmion, Glapthorne, Cartwright and Mayne, failing to catch the true underlying spirit of Jonson's morality, painted dull coarse pictures of the lowest stratum of London society, with the constantly repeated assertion that the purpose was to scourge vice. Certain subjects of satire, emphasized by Jonson, particularly the cant and hypocrisy of the Puritans, the meannesses and crimes of avarice, the foolish fads of Ladies Collegiate, the projects of sharpers, the credulity of news-gatherers, and a slavish pursuit of the fashions of the day, are used by one after another of the "Sons" until it seems as if these follies and abuses should have been forever whipped out of English life.

Jonson taught contemporaries and disciples the value of careful workmanship, regard within certain limits for the dramatic unities, and that artistic logic which creates each part with conscious reference to the whole. The greater writers seized and applied these principles; the lesser proceeded to copy or adopt particular situations. The favorite ones were: the school of fashion introduced in The Devil is an Ass, the grouping of irregular humorists first found in Every Man in His II umor and Every Man out of IHis Humor, the transformation effected by marriage and also the device for making the contract void set forth in The Silent Woman, the scheme for systematic news-gathering in The Staple of News, and the confederacy of rogues in Volpone and The Alchemist.

The minor characteristics of Jonson's comedy reappear now and again in other writers. His background of classical learning, and the classical allusions and quotations 
wrought into the very fiber of his plays, only such men as were themselves classical scholars, Chapman, Marston, or Randolph, could in any sense approach; but his example certainly increased the contemporary liking for passing allusions to classical authors and literature. His influence combined with that of Middleton to teach local color and realistic portrayal of everyday life, and in this respect we may be sure that Field and Brome, May and Randolph, learned largely from Jonson. Brome followed him in selfconscious attitude and intellectual appeal; Chapman and Randolph, in the use of a commentator on the action; Marston and Marmion, in their inductions; Shirley and Brome, in independent prologues and epilogues addressed to the public.

Whether Jonson's theories, when applied, resulted in living plays or dull imitations depended largely on the personal powers of the writers applying them, and many of his followers were neither great thinkers nor great poets. However, "the Sons'" besetting sins of pedantry, didacticism, abstraction, allegory, caricature, artificiality, and sameness, were dangers inherent in his methods. On the other hand, he gave to English comedy greater variety of character and more effective portrayal of the manners and humors of men, more careful and logical construction, and a moral earnestness that was needed to counteract the influence of Middleton and Fletcher. 


\section{BIBLIOGRAPHY}

Aronstein, Philipp: Ben Jonson's Theorie des Lustspiels. Anglia, XVII (neue folge, V).

Beaumont and Fletcher: Works, with notes and a biographical memoir by Alexander Dyce, 2 vols. Boston and New York, 1854. Brome, Richard: Dramatic Works, 3 vols. London, 1873.

Cartwright, William: The Ordinary, in Dodsley's Old English Plays, ed. by W. Carew Hazlitt, Vol. XII. London, 1875.

Castelain, Maurice: Ben Jonson L'Homme et l'Euvre. Paris, 1907. Chapman, George; Plays, ed. with notes by R. H. Shepherd. London, 1889.

Cockayne, Sir Aston: Dramatic Works, ed. by J. Maidment and W. H. Logan. Edinburgh and London, 1874.

Davenant, Sir William: Dramatic Works, ed. by J. Maidment and W. H. Logan, 5 vols. Edinburgh and London, 1872.

Davenport, Robert: Works, in Old English Plays, ed. by A. H. Bullen, New Series, Vol. III. London, 1890.

Dryden, John: Of Dramatic Poesy, in Essays, ed. by W. P. Ker. Oxford, 1900.

Every Woman in Her Humor: ed. by A. H. Bullen in Old English Plays, vol. IV. London, 1885.

Fair Maid of the Exchange: ed. by Barron Field in Publications of the Shakespeare Society. London, 1846.

Field, Nathaniel: Plays, ed. by A. W. Verity, in Nero and Other Plays, Mermaid Series. London, 1888.

Fleay, F. G.: Annals of the Career of Nathaniel Field. Eng. Stud., XIII, 1889.

- A Chronicle History of the English Stage. London, 1890. A Biographical Chronicle of the English Drama, 2 vols. London, 1891.

- The Life and Work of Shakespeare. London, 1886.

Glapthorne, Henry: Works, 2 vols. London, 1874.

Greg, W. W.: Edition of Henslowe's Diary. London, Part I, 1904; Part II, 1908.

Hathaway, Charles M.: Edition of The Alchemist, with introduction and notes, Yale Studies in English, XVII. New York, 1903.

Hazlitt, William: Lectures on the English Comic Writers, ed. by

W. Carew Hazlitt. London, 1884.

Henry, Aurelia: Edition of Epicane, with introduction and notes, Yale Studies in English, XXXI. New York, 1906.

Jonson, Ben: Works, with notes and a biographical memoir by 
William Gifiord, ed. by Francis Cunningham, 3 vols. London, 1875.

ton, 1892 .

- Best Plays, ed. by Brinsley Nicholson, with an introduction by C. H. Herford. London and New York, 1893-94.

Koeppel, Emil: Studien über Shakespeare's Wirkung auf Zeitgenössische Dramatiker, in Materialen zur Kunde des älteren Englischen Dramas, ed. by W. Bang. Louvain, 1905.

- Quellen-Studien zu den Dramen Ben Jonson's, John Marston's und Beaumont und Fletcher's. Erlangen und Leipzig, 1895.

Lamb, Charles: Dramatic Essays, and Specimens of the English Dramatic Poets, in Works, ed. by Percy Fitzgerald, Temple edition. London and Philadelphia, 1897.

Langbaine, Gerard: An Account of the English Dramatic Poets. Oxford, 1691.

Marmion, Shakerley: Dramatic Works, ed. by J. Maidment and W. H. Logan. Edinburgh and London, 1875.

Marston, John: Works, ed. by A. H. Bullen, 3 vols. Boston and New York, 1887.

Massinger, Philip: Plays, ed. by Francis Cunningham from the text of William Gifford. London, 1870.

- Best Plays, ed. with an introduction and notes, by Arthur Symons. London, 1887.

May, Thomas: The Old Couple, in Dodsley's Old English Plays, ed. by W. Carew Hazlitt, vol. XII. London, 1875.

Mayne, Jasper: The City Match, in Dodsley's Old English Plays, ed. by W. Carew Hazlitt, vol. XIII. London, 1875.

Nabbes, Thomas: Works, in Old English Plays, ed. by A. H. Bullen, New Series, vols. I and II. London, 1887.

Newcastle, Duke of, William Cavendish: The Country Captain and The Variety. London, 1649.

Penniman, Josiah H.: The War of the Theaters. Boston, 1897.

Randolph, Thomas: Works, ed. by W. Carew Hazlitt, 2 vols. London, 1875.

Schelling, Felix E.: Elizabethan Drama, 1558-1642, 2 vols. Boston and New York, 1908.

- Ben Jonson and the Classical School. Publications of the Modern Language Association of America, vol. XIII, No. $2,1898$.

Edition of Eastward Hoe and The Alchemist, with introduction and notes, Belles-Lettres Series. Boston and London, 1903.

Shakespeare, William: Works, ed. by H. N. Hudson, 12 vols. Boston, 1881. 
Shirley, James: Works, with notes by William Gifford, and biography by Alexander Dyce, 6 vols. London, 1833.

- Best Plays, ed. by Edmund Gosse. London, 1888.

Swinburne, A. C.: A Study of Ben Jonson. London, 1889.

- - Richard Brome. Fortnightly Review, LVII, 1892.

Symonds, J. A.: Ben Jonson. London, 1888.

Richard Brome. Academy, March, 1874.

Ward, A. W.: A History of English Dramatic Literature, 3 vols. London and New York, 1899.

Wilke, W.: Anwendung der Rhyme-test und Double-endings-test auf Ben Jonson's Dramen. Anglia, X.

Wood, Anthony: Athenae Oxonienses, ed. by Philip Bliss. London, 1813.

Woodbridge, Elisabeth: Studies in Jonson's Comedy, Yale Studie in English, V. Boston, New York and London, 1898. 
wor.

$\therefore$ 


\section{INDEX}

Admiral's Men, 20.

Alchemist, 6, 10, 13, 15, 21, 50,

$66,70,85,94,114,123$.

Allegory, 12-13, 40, 88.

All Fools, 21.

All's Well That Ends Well, 30,

$31,34$.

Amends for Ladies, 54, 55, 56.

Amyntas, 80.

Anachronisms, 8.

Antigone, 77.

Antipodes, 59, 60, 63, 65, 69, 71.

Antiquary, 90-92.

Antonio and Mellida, 25.

Apollo Club, 3-5, 42.

Aristippus, 80.

Aristophanes, 7, 80, 83.

Authority, Jonson's sense of, 11.

Ball, 46, 50, 111.

Bartholomew Fair, 13, 15, 57, 66, $69,72,85$.

Beaumont, Francis, 3, 18, 19, $36-42,120,121$.

Blind Beggar of Alexandria, 1920.

Bobadil, 40, 116.

Bride, 107, 109.

Brome, Alexander, 59.

Brome, Richard, 52, 57-75, 89, 106, 121 .

Bullen, A. H., 106, 107.

Bunyan, 13.

Burbage, Richard, 53.

Cambridge University, 80.

Carlyle, Thomas, 7.

Cartwright, William, 52, 93. 100, 122.

Case Is Altered, 30, 61.
Catiline, 37, 38, 53.

Cavendish, William, Earl of Newcastle, 52, 100, 112-117, 122.

Censor, Attitude of, 6 .

Chapman, George, 18, 19-24, 120, 121.

Characters of Jonsonian Comedy, 11-14.

Chaucer, 10.

Children of the Chapel, 52.

Cicero, 26, 93.

City Madam, 43.

City Match, 100-103.

City Night-Cap, 79.

City Wit, 58, 60, 63, 68-70, 72.

Classicism, of Jonson, 7; Chapman, 19; Marston, 24, 26; Randolph, 83.

Cleopatra, 77.

Cockayne, Sir Aston, 52, 59, 80, 110-112, 122.

Coleridge, S. T., 15.

College Drama, 80.

Comedy of Humors, 20.

Conceited Pedlar, 80.

Congreve, William, 112.

Construction of plays, 15, 43, 69, 107.

Conversations, 25, 27, 53.

Country Captain, 112, 115.

Court Beggar, 59-60, 63, 65, 70, 72.

Covent Garden, 106, 108.

Cunningham, Francis, 25.

Cynthia's Revels, 8, 14, 15, 16, $35,53,88$.

Davenant, Sir William, 52, 117 119, 122. 
Davenport, Robert, 52, 79, 122. Ford, John, 59.

Dekker, Thomas, 59.

Demoiselle, 62, 66, 72.

Forest, The, 9.

Fortune, The, 55.

Devil Is An Ass, 44, 49, 65, 70, 78, 115, 123.

Four Triumphs, 39.

Fraunces, Edward, 83.

Devil Tavern, 3, 45, 59, 76, 80, Fuller, Thomas, 29.

$89,112$.

Didacticism, 63, 79, 85 .

Discoveries, 2.

Donne, John, 111.

Drayton, Michael, 30, 111.

Drummond of Hawthornden, 20, 38.

Dryden, John, 11, 112.

Duke's Mistress, 47.

Dutch Courtesan, 24, 27.

Dyce, Alexander, 38.

Eastward Hoe, 20, 25, 28.

English Moor, 59-60.

Epiccne, 15, 31, 37, 100, 101, 123.

Ethical Aims, of Jonson, 5-6, 10; Brome, 63; May, 78; Randolph, 85; Marmion, 90; Nabbes, 108.

Every man in His Humor, 1, 2, $19,20,21,29,31,73,116$.

Every Man Out of His Humor, $6,7,12,14,16,20,22,31$, $35,48,73,123$.

Every Woman in Her Humor, $34,35-36,120$.

Example, 46.

Fair Maid of the Exchange, 3435.

Faithful Shepherdess, 38.

Falstaff, 32, 120.

Fault in Friendship, 58.

Fawn, 26, 28.

Field, Nathaniel, 52-57, 122.

Fine Companion, 89.

Fleay, F. G., 26, 34, 77, $120 . \quad$ Jealous Lovers, 80, 85, 88.

Fletcher, John, 16, 19, 36-42, 60, Jonsonus Virbius, 77, 90, 93, $77,120,121$.
Gamester, 46.

Gentleman Usher, 23.

Giles, Nathaniel, 53.

Glapthorne, Henry, 52, 103-106, 122.

Grateful Servant, 45.

Gray's Inn, 76.

Gulling, 16, 24.

Habington, William, 45.

Hall, John, 59.

Heir, 77.

Henry, Aurelia, 31, 102.

Henry IV, 31.

Henry $V, 31,33$.

Henslowe's Diary, 20.

Heroic drama, 118.

Herrick, Robert, 4.

Hey for Honesty, 80, 82, 85.

Heywood, Thomas, 9, 89.

Hollander, 103, 104, 105.

Holland's Leaguer, 90.

Hope, The, 52.

Humors, 11-12, 27, 30-34, 49, 56, 71-73, 79, 88, 91, 108, 111, 117, 118-120, 122.

Humorous Courtier, 51.

Humorous Day's Mirth, 19, 20, 21.

Humorous Lieutenant, 39-40.

Humorous Lovers, 114.

Hyde Park, 46, 115.

Inductions, 15-16, 25, 124. 100. 
Jovial Crew, 59, 69, 71, 73, 75, 119.

Julius Caesar, 80, 85, 88.

King and No King, 40.

Knight of the Burning Pestle, $39,40$.

Koeppel, Emil, 30, 41, 60.

Ladies Collegiate, 49, 123.

Ladies' Privilege, 103.

Lady of Pleasure, 46, 115.

Langbaine, Gerard, 77, 93, 106, $112,114$.

Learning of Jonson, 8.

Leges Convivales, 4-5.

Lines to Shakespeare, 30.

Little French Lawyer, 40.

Love in a Maze, 51.

Lovesick Court, 60, 71, 74.

Love's Welcome at Bolsover, 112.

Love's Welcome at Welbeck, 112, 113.

Love Tricks, 45, 46, 48.

Lowell, J. R., 5.

Lucan, 77.

Mad Couple Well Matched, 60, 63.

Magnetic Lady, 13, 115.

Malcontent, 25, 27.

Malvolio, 33, 120.

Marmion, Shakerley, 52, 89-93, 106, 122.

Marston, Jolin, 19, 24-29, 120.

Martial, 26, 77.

Massinger, Philip, 19, 42-44, 60, $111,120,121$.

Masque of Augurs, 45.

Masques, of Jonson, 7; of Shirley, 45.

May Day, 23.

May, Thomas, 52, 76-79, 121.

Mayne, Jasper, 52, 100-103, 122.

Mleasure for Measure, 30.

Merchant of Venice, 31.
Mercury Vindicated, 13.

Mermaid, The, 3, 29.

Merry Wives of Windsor, 31, 32.

Middleton, Thomas, 30, 42, 46.

Monsieur D'Olive, 23, 24.

Moralities, 12.

Much Ado About Nothing, 105.

Muses' Looking-Glass, S0, 84, 88.

Nabbes, Thomas, 52, 89, 106$110,122$.

Nature, Jonson's lack of feeling for, 9-10.

Neptune's Triumph, 45, 99.

New Academy, 63, 73, 75.

Newcastle, Duchess of, 112, 115.

Newcastle, Duke of. See Cavendish, William.

Newington Butts, 55 .

New Inn, 60, 61, 83.

Neus from Plymouth, 118.

New Way to Pay Old Debts, 43.

New Trick to Cheat the Devil, 79.

Northern Lass, 57, 62, 66, 69, 73.

Novella, 60, 70.

Obstinate Lady, 111.

Old Couple, 77-79.

Ordinary, 94-100.

Ovid, 26.

Oxford University, 80, 89.

Personality of Jonson, 3.

Pilgrim's Progress, 13.

Platonic love, 103, 118.

Platonic Lovers, 118.

Plautus, $7,19,22,39,83$.

Plots of Jonson's Comedy, 14-

15.

Poetaster, 14, 15, 20, 31, 35.

Project, 65, 104.

Puritans, 24, 66, 85, 99, 102, 104.

Queen's Exchange, 60, 62. 
Queen and Concubine, 60, 75.

Randolph, Thomas, 52, 80-89, 121.

Realism, 64, 75.

Renaissance, 10.

Restoration, 115, 117, 118.

Roarers, 66, 104.

Romance, 9.

Romantic School, 36, 44, 77, 118. Romeo and Juliet, 31.

Rule a Wife and Have a Wife, $39,41$.

Satire, 7, 12, 27, 40-41, 43, 54, 116.

Schelling, F. E., 7, 31, 88.

School of Compliment, 49, 70.

Scornful Lady, 39.

Sejanus, 20, 25, 29.

Seneca, 26.

Shadwell, Thomas, 112.

Shakespeare, 9, 19, 29-34, 60, 120.

Shirley, James, 19, 44-51, 80, $107,112,115,120,121$.

Silent Woman. See Epicœne.

Sparagus Garden, 61, 63, 71.

Staple of News, 9, 13, 14, 47, 117.

Suckling, Sir John, 111.

Swift, Jonathan, 7.

Swinburne, Algernon, 5, 21, 70.

Symonds, J. A., 7, 8.

Tamer Tamed, 39.

Tatham, John, 59.

Terence, 7, 19, 22, 39, 83.

Timber, 30.

Tottenham Court, 106, 108.
Tourneur, Cyril, 29.

Triumph of Peace, 45.

Triumphant Widow, 115.

Twelfth Night, 31, 33.

Types of character, 14, 40.

Underwoods, The, 20.

Unities, of drama, 11.

Variety, 114, 116.

Vergil, 77.

Versification, of Jonson, 16-17;

Beaumont and Fletcher, 41;

Brome, 75.

Volpone, 6, 10, 13, 14, 15, 20, $21,38,70,99,123$.

War of the Theaters, 25.

Ward, A. W., 22, 60, 71, 73, 88, 93, 99.

Watkyns, Rowland, 81.

Wedding, 46, 50, 115.

Weeding of Covent Garden, 60, 64, 66, 69, 72, 75 .

What You Will, 25, 26, 28.

Widow's Tears, 23.

Wife of Bath, 36.

Wilkins, G., 29.

Wit in a Constable, 103, 105.

Wit Without Money, 40.

Wits, 118.

Witty Fair One, 46, 115.

Woman Hater, 39.

Woman Is a Weathercock, 53, $54,55,56$.

World in the Moon, 71.

Wood, Anthony, 93, 110, 115.

Woodbridge, Elizabeth, 11, 14.

Young Admiral, 49, 105. 


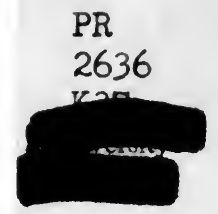

Kerr, Mina

Influence of Ben Jonson on English comedy

PLEASE DO NOT REMOVE

CARDS OR SLIPS FROM THIS POCKET

UNIVERSITY OF TORONTO LIBRARY 
